\title{
Social Transfers and Growth: A Review
}

Armando Barrientos ${ }^{1}$,

James Scott ${ }^{2}$

July 2008

1,2 Brooks World Poverty Institute, University of Manchester

Armando.barrientos@manchester.ac.uk

Brooks World Poverty Institute

BWPI Working Paper 52

ISBN : 978-1-906518-51-6

Creating and sharing knowledge to help end poverty 


\begin{abstract}
A considerable and growing literature exists on social transfers in developing countries, that is, direct transfers in cash or kind to individuals or households in poverty. Many studies have examined the contribution social transfers can make to reducing poverty and vulnerability in the developing world, but less attention has been paid to how social transfers might affect growth. This Review examines the available evidence on the effects social transfers may be expected to have on growth at the micro-level. It identifies and assesses a number of pathways through which social transfers can potentially contribute either to enhancing or impeding growth.

This paper argues that in assessing the growth impacts of social transfers it is important to focus on the poor and their circumstances. The discussion of the linkages between social transfers and growth in developed countries focuses on cross-country empirical studies, testing the hypothesis that if social expenditures are harmful to growth performance then they will show a negative correlation with growth across a sample of countries.
\end{abstract}

Keywords: Bangladesh, Brazil, Ethiopia, Mozambique, social transfers, micro-credit, education, resource allocation

\title{
Acknowledgements
}

The paper was commissioned by the Equity and Rights Team at the UK Department for International Development, Policy and Research Division, London. It has benefited from extensive comments on an earlier version by Katie Fawkner-Corbett, Rahul Malhotra, Catherine Arnold, Tim Waites, Rebecca Calder, and others at DFID London; and from members of DAC's POVNET Task Team on Social Protection and Employment. Tim Robertson, Claudio Fumo, Rebecca Calder and Ernesto Jeger, DFID Social Development Advisors, provided valuable information at country level for Ethiopia, Mozambique, Bangladesh and Brazil respectively. The views and opinion expressed, and remaining errors, are those of the author alone.

Armando Barrientos is a Senior Researcher with the Chronic Poverty Research Centre, leading research on Insecurity, Risk and Vulnerability. He is also an Associate Director of the Brooks World Poverty Institute at the University of Manchester. His research interests focus on the linkages existing between social protection and labour markets in developing countries, and policies addressing poverty, vulnerability, and population ageing. 


\section{Executive Summary}

A considerable and growing literature exists on social transfers in developing countries, that is, direct transfers in cash or kind to individuals or households in poverty. Many studies have examined the contribution social transfers can make to reducing poverty and vulnerability in the developing world, but less attention has been paid to how social transfers might affect growth. This Review examines the available evidence on the effects social transfers may be expected to have on growth at the micro-level. It identifies and assesses a number of pathways through which social transfers can potentially contribute either to enhancing or impeding growth. Quantification of these effects remains difficult. Overall, the Review finds that there is very little evidence to justify concerns over detrimental effects of social transfers on growth, while some evidence can be found to support the view that social transfers, providing they are designed and implemented effectively, are capable of strengthening some micro-level outcomes that are intermediate to growth. Although social transfers should not be seen as a 'silver bullet' that will cure all poverty-related problems, they offer an important tool to developing countries for alleviating current poverty and strengthening micro-level outcomes that will support growth.

This Review argues that in assessing the growth impacts of social transfers it is important to focus on the poor and their circumstances. The discussion of the linkages between social transfers and growth in developed countries has focused on cross-country empirical studies, testing the hypothesis that if social expenditures are harmful to growth performance then they will show a negative correlation with growth across a sample of countries. Despite considerable resources having been invested on this approach no clear results have emerged. Given this and the lack of reliable data for many developing countries, such an approach is unsuitable for examining such countries. Instead, this Review argues that we must focus on the poor and the particular circumstances that they face, recognising that those in poverty generally face a qualitatively different set of opportunities to those better off.

Many of the poorest households may find themselves in poverty traps, locked into a cycle of low income and limited opportunity. For example, lacking sufficient assets to use as collateral, poor households are unable to access credit and hence unable to make the investments that might lead them out of poverty. The poor, therefore, are likely to face severely restricted opportunities, which serve to maintain them in poverty. Social transfers can play a role in overcoming these restrictions by shifting poor households out of such poverty traps and onto a growth path.

This Review seeks to construct a basic framework for tracing the growth effects of social transfers. It identifies three processes through which transfers can lead to investment and growth at the household level. These are:

- The extent to which social transfers are able to lift credit constraints. When regular and reliable transfers can alleviate credit constraints by facilitating access to bank loans without the need for collateral, and, when combined with other interventions such as micro-credit, can extend credit to the poorest households. 
- The extent to which social transfers provide greater certainty and security. Poor households adopt a range of strategies to protect their consumption and assets from shocks. Insecure and precarious livelihoods are bound to limit investment by poor households, whilst leading to inefficient use of resources, for example by forcing rural poor households to opt for low-risk/low-return crops and production methods. Social transfers can improve household security, particularly when incorporating insurance elements, leading to a more efficient use of resources.

- The extent to which social transfers facilitate improved household resource allocation and dynamics. Decisions about the allocation of time and resources within the household reflect unequal bargaining influence, leading to inefficiencies which can prevent optimum investment and income growth. Channelling transfers to particular members of the household, notably women, can improve household dynamics, with a shift in consumption to child-related goods and services and more efficient resource allocation.

Social transfers have also been shown to have a significant positive effect on human capital accumulation. Many programmes include conditions requiring recipients to engage in human or physical capital accumulation, such as through sending children to school, attending health clinics or building local infrastructure. Even without such conditionality, it has been found that recipients frequently engage in human capital and productive investment. The evidence from a range of programmes in developing countries across the world is that there is a significant improvement in, for instance, the school attendance of the children in beneficiary households. Given the strong correlation between the level of schooling attained and labour market opportunity it is expected that social transfers will contribute to higher future growth, although there is a considerable lag in the emergence of this effect making precise measurement difficult. Similarly, social transfers have been shown to improve the health status of beneficiaries, which is also likely to improve earnings and productivity.

\section{Figure 1}

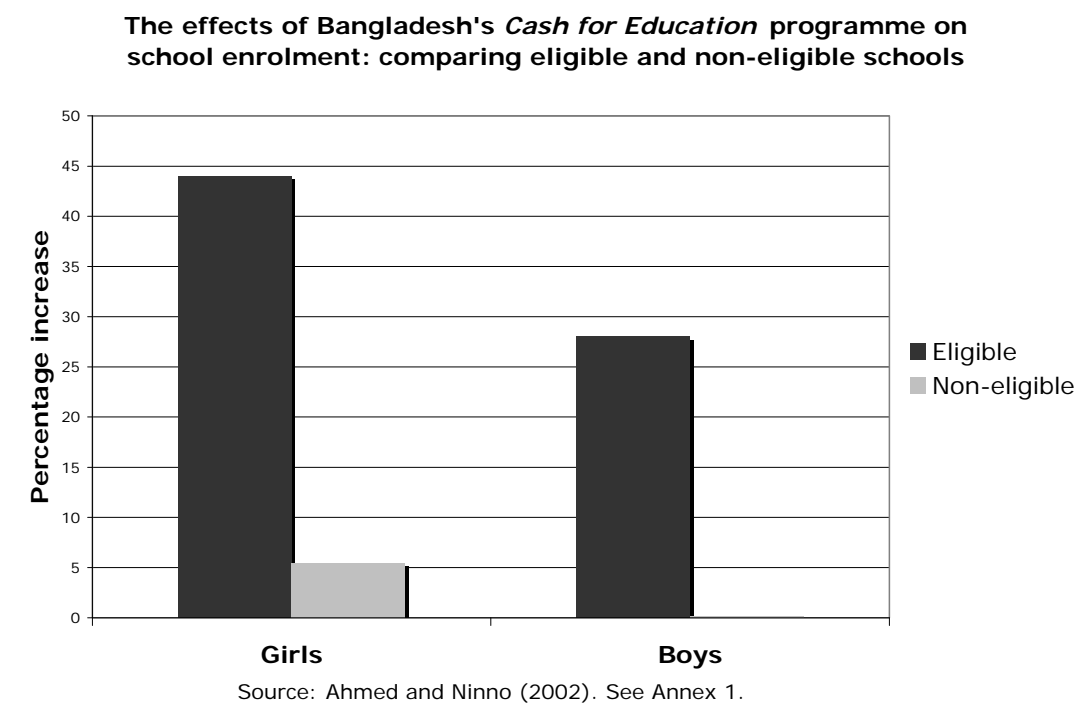

The literature on social transfers in developed countries has raised potentially adverse effects of social transfers on growth. They focus particularly on the impact of transfers on incentives to work and save among beneficiaries. Standard economic theory suggests that the rise in income among beneficiaries could lead to a decline in labour supply, which in turn would undermine growth. The empirical evidence for developing countries examined in this Review, however, suggests that the adverse effect predicted by theory is generally outweighed by positive effects 
arising from a re-allocation of labour within beneficiary households. Social transfers which include school attendance requirements aim to secure reductions in child labour, thus helping to break the persistence of poverty through generations. Labour force participation rates have been found to decline considerably among the elderly in response to social pensions. However, the reduction in labour supply from children and the elderly is normally more than compensated for by increases in labour supply by other household members. For example, in South Africa it was found that the social pension enabled other household members to migrate in search of work. In summary, there is scant evidence that social transfers have net adverse labour supply effects on beneficiaries.

\section{The empirical evidence suggests that the adverse effects that social transfer programmes are predicted to have on growth are generally found either not to be borne out by empirical evidence, or to be outweighed by positive.}

Similarly, a potentially adverse effect on saving induced by social transfer programmes finds no empirical support. Studies suggest that beneficiaries tend to increase, rather than reduce, their savings for a variety of reasons. There is little in the literature discussing the impact of transfers on saving among the population as a whole, but since developing countries tend to have weak social insurance provision it is unlikely that people will significantly alter their saving rates in response to the introduction of social transfer programmes. Overall, therefore, the evidence suggests that social transfers tend to increase rather than decrease saving.

This Review raises a number of policy implications for the design of social transfer programmes.

Firstly, social transfers can facilitate household investment through raising household income, and can help overcome problems of access to credit for the poor. However, in order to maximise the effects on investment, social transfers need to be regular and reliable, with beneficiary households having clear and credible information on the size, time and schedule of entitlements.

Secondly, the level of transfer is important. Not surprisingly, the evidence suggests that low level transfers have smaller effects on households' capacity to exit poverty. The literature on poverty traps points to the presence of thresholds, below which exit is unlikely. The level of transfers need to be set with due attention to households' capacity to engage in investment and exit poverty. That said, in social transfers conditional on labour supply, setting the level of transfer below the market wage ensures self-selection and minimises adverse incentives to work.

Thirdly, it is important that transfers do not include eligibility conditions that function as incentives for asset depletion. That is, programmes that base eligibility on relatively liquid assets such as livestock could provide an incentive to divest such assets. Similarly, eligibility conditions should not include inactivity tests, as is sometimes the case with social pensions and family allowances. It is important that beneficiaries are able to continue paid work without losing the transfer, in order to avoid negative effects on labour supply.

Fourthly, programmes should be designed in ways that facilitate household re-allocation of productive resources. This is an area that has not received sufficient attention, but the limited findings available suggest that transfers can and do lead to improved household allocation of productive resources. This effect appears to have an important gender dimension, suggesting that programme design should consider whether channelling the transfer through particular household members, notably women, has an effect on household investment. For example, by 
making women the direct recipients of transfers, their bargaining position within the household is strengthened, which has been found to increase the amount of household income spent on children. The gender of the transfer recipient can therefore have an effect on the degree to which the transfer stimulates investment in human capital.

Lastly, the design of social transfers could include complementary asset accumulation interventions. This includes both human and productive assets. In terms of human capital assets, social transfers will be most effective in facilitating the accumulation of these assets when combined with programmes that ensure basic services, especially health and education, are available in appropriate quantity and quality. With regard to productive assets, some schemes, such as BRAC's Targeting the Ultra Poor Programme in Bangladesh have combined transfers and human capital interventions with micro-credit and skills training. Such complementary programmes will help to maximise the benefits of social transfers.

This Review shows that there are a number of potential channels and processes through which social transfers may improve growth at the micro-level. It begins to develop a framework through which the evidence from existing programmes can be organised in order to understand and assess this link. Although much remains uncertain, precise quantification is difficult and large gaps in evidence on impact persist, the overall picture is positive. The most frequently cited potential negative effects of social transfers are not supported empirically, while substantial evidence has emerged for social transfers playing a significant role in improving human capital. Furthermore, transfers have been shown to help the poor break free of poverty traps and move them onto a cycle of growth. Although we must guard against viewing social transfers as a panacea that will solve all problems of poverty, when properly designed and delivered, social transfers are capable of making a significant contribution to improving the current lives of the poor and hold the promise of reducing persistent poverty. A greater understanding of the channels through which micro-level growth is facilitated by social transfers will help in designing programmes in such a way as to maximise their impact on present and future poverty. 


\section{Introduction}

A feature of the last decade has been the emergence of large scale social transfer programmes in some developing countries focused on the poor and poorest groups. There is a large and growing literature focused on assessing the poverty reduction effectiveness of these programmes (Samson, 2007). The broad findings from this literature, covering social transfers of different types and in different settings, suggest that they have the potential to make a significant difference to poverty and vulnerability in the developing world. Less attention has been paid to examining the potential impact of social transfers on growth and development. This is understandable given that large- scale social transfer programmes have been introduced only recently in developing countries, and that their main objective is the reduction of poverty and vulnerability. However, the rapid spread of social transfers and the concern, often expressed by policy-makers, to ensure consistency with growth and development objectives point to the need to piece together and weigh up the available evidence on the potential growth effects of large scale social transfers. The main aim of this Review is to throw light on how social transfers may affect growth at the micro-level, by setting out a basic framework with which to collect, organise, and assess available evidence.

There are alternative entry points into the study of the effect of social transfers on growth which may be usefully noted at the outset. Research on the welfare state in developed countries is strongly influenced by the view that social protection must have considerable autonomy from economic policy. In The Great Transformation, Polanyi argues that market economies are sustained by a process of commodification that is by transforming social relations into commodities that can be traded (Polanyi, 1957). This is problematic in respect to labour and natural resources, because the conditions for social reproduction can be acutely undermined by unregulated market forces. Unemployment and poverty are often a direct consequence of variations in labour demand. In this context, the role of social protection, and social transfers, in ensuring social reproduction requires autonomy from economic policy. The approach of welfare economics, in contrast, is to demonstrate that the main role of social policy is to address market failure, thus denying it autonomy from economic policy. Economists and social policy researchers would be right to complain about this simplistic characterisation, but it helps to make the point that the evidence gathered in this paper will be considered by readers applying different normative frameworks. For developing country researchers, there is strong common ground and consensus in the view that all public policy needs to be assessed in terms of its contribution to development. Studying the effects of social transfers on growth at the micro-level and for households in poverty is of intrinsic interest to them.

For the purposes of this Review, social transfers describe programmes providing direct transfers in cash or kind to individuals or households with the primary objective of reducing poverty and vulnerability. In the main, these programmes are non-contributory, financed from tax revenues (where international aid is involved, tax revenues are collected in a different jurisdiction), and are focused on the poor and poorest groups. Increasingly, social transfer programmes combine direct transfers with other interventions, access to basic services or credit, for example. We are interested in programmes where direct transfers are the main element. 


\section{Social transfers complement growth strategies}

In the last decade or so, large scale social transfers have emerged in some developing countries, predominantly middle income countries, as a core component of poverty reduction strategies. At the same time a number of low income countries are piloting small-scale social transfers to test their potential and to assess their effectiveness in a different environment. The linkages existing between social transfers and growth strategies flow in both directions. Strong economic growth is essential for poverty reduction and it has been estimated that growth has accounted for up to 80 percent of poverty reduction since 1980. Growth creates economic opportunities and employment as well as the fiscal space to address poverty and vulnerability with public programmes. Where it is pro-poor, growth reduces poverty directly, while also facilitating the extension of social protection. At the same time, social transfers are important in ensuring that economic growth reaches those in poverty, and particularly the poorest. Welldesigned and effective social transfers have a role in extending economic opportunity to the most vulnerable.

The emergence of social transfers in developing countries is in no small part a response to the uneven distribution of growth in the developing world. There is considerable variation in growthrelated poverty reduction both across countries and within countries (Chen and Ravaillon, 2004), with the implication that in the absence of direct policy interventions large numbers of people in the developing world will remain in poverty. Rough estimates suggest that as many as 40 percent of those in poverty will stay poor for long periods, even across generations (CPRC, 2005). Summary data from Brazil for the two decades beginning in 1976 illustrates this point. Table 1 below shows that while income per capita rose consistently in this period, and the incidence of moderate poverty (measured with a US $\$ 2$ poverty line) declined, the incidence of extreme poverty (measured with a US $\$ 1$ poverty line) increased consistently over time.

Table 1. Growth and poverty trends in urban Brazil 1976-1996

\begin{tabular}{|l|r|r|r|r||}
\hline \hline & 1976 & 1981 & 1985 & 1996 \\
\hline GNP per capita (1996Rs) & 4004 & 4442 & 4540 & 4945 \\
\hline $\begin{array}{l}\text { Mean urban household income per } \\
\text { capita (1996Rs) }\end{array}$ & 265.1 & 239.08 & 243.15 & 276.46 \\
\hline Poverty headcount (z=1US\$) & 6.81 & 7.27 & 7.58 & 9.22 \\
\hline Poverty headcount (z=2US\$) & 22.09 & 21.49 & 22.74 & 21.76 \\
\hline $\begin{array}{l}\text { Source: F. H. G. Ferreira and R. Paes de Barros, 'The Slippery Slope: Explaining the increase in } \\
\text { extreme poverty in urban Brazil 1976-96', in F. Bourguignon, F. H. G. Ferreira and N. Lustig (eds.), } \\
\text { The Microeconomics of Income Distribution Dynamics, (Washington DC, 2005), pp. 83-124 }\end{array}$ \\
\hline
\end{tabular}

Policies to promote economic growth are likely to be more effective in reducing poverty if they are complemented with policies which extend opportunity to those who are least advantaged. Social transfers, and more generally social protection, can help ensure that growth generates opportunities across the board, (Bourguignon, 2004). In 2001, the need to address the persistence of extreme poverty in Brazil led policy makers to extend the previously regional programme Bolsa Escola on a national basis. The programme provided transfers to households in poverty with children of school age, conditional on children attending school on a 
regular basis. It was later extended to all households in poverty as Bolsa Familia. By extending the benefits of economic growth, albeit to a small degree, to those left behind, social protection can also contribute to the maintenance of social cohesion. That said, for social transfer programmes to build social cohesion it is critical that they have a strong level of support across society, in particular from those who bear the tax burden.

\section{The emergence of large-scale social transfer programmes}

Several factors have combined to create the conditions for the emergence of large- scale social transfer programmes in developing countries. The Millennium Development Goals (MDGs) have provided a focus for concerted national and international action on poverty reduction. In Latin America, adjustment and liberalisation led to a rapid rise in poverty, much of which persisted through the recovery phase. In Asia, rapid economic transformation and financial crises have led to the expansion of social transfers. In Africa, the challenge is to replace emergency aid with predictable international assistance. New modalities of international assistance have helped create the conditions for large-scale transfer programmes in low income countries.

The emergence of large-scale social transfer programmes in developing countries has been swift. Most of these have emerged in middle-income countries, but there are also examples from low-income countries. Middle income countries have greater capacity, both financial and administrative, to establish social transfer programmes than low income countries. It is important not to over-emphasise this point, as social transfers are commonly introduced in rural and poorer areas in middle income countries, often with high incidence of poverty and limited delivery capacity. The Minimum Living Standards in China reaches 24 million households, the National Rural Employment Guarantee Scheme (NREGS) in India will reach 24 million households when fully implemented, the target for the Safety Net programme in Indonesia is 15 million households, Bolsa Familia reaches a further 12 million households, Ethiopia's Productive Safety Net Programme (PSNP) reaches 7 million people, and OPORTUNIDADES in Mexico another 5 million households. Other countries are piloting social transfer programmes (eg Zambia, Ghana, Nigeria). These, and the social transfer programmes in medium size and smaller countries, have the potential to make a significant reduction in poverty globally. Table 1 provides summary information for selected social transfer programmes.

Transfer programmes in developing countries show considerable variety in programme design. Unconditional transfers, like South Africa's social pension, raise the income of households in poverty and therefore their purchasing power. Conditional transfers combine income supplements with utilisation of basic services or with improvements in infrastructure. Social transfers conditional on investment in human development, Bolsa Familia for example, tie the transfer to school attendance and primary health care utilisation with the objective of reducing intergenerational poverty persistence. Social transfers conditioned on labour supply link the transfer to work on local infrastructure development (Ethiopia's PSNP or India's NREGS), or a mix of infrastructure development, community work, or education or training (Argentina's Unemployed Heads of Households Public Works programme). 
Table 2. Summary information on selected social transfer programmes in developing countries

\begin{tabular}{|c|c|c|c|c|c|c|}
\hline Programme & Country & Date started & $\begin{array}{l}\text { Type of } \\
\text { transfer }\end{array}$ & Target group & Coverage & Transfer level \\
\hline $\begin{array}{l}\text { Challenging the } \\
\text { Frontiers of } \\
\text { Poverty Reduction/ } \\
\text { Targeting the Ultra } \\
\text { Poor }\end{array}$ & Bangladesh & 2002 & $\begin{array}{c}\text { Input grants - } \\
\text { asset transfers, } \\
\text { cash transfers, } \\
\text { health, } \\
\text { microcredit }\end{array}$ & $\begin{array}{l}\text { Women in the poorest } \\
\text { households. }\end{array}$ & $\begin{array}{l}100,000 \text { women } \\
\text { benefited between } \\
2002 \text { and } 2007 .\end{array}$ & $\begin{array}{c}\text { Taka } 300 \text { a month. Also enterprise } \\
\text { development training, asset transfers. }\end{array}$ \\
\hline BONO DIGNIDAD & Bolivia & $\begin{array}{l}\text { 1997, changed in } \\
2008\end{array}$ & Cash & Universal & 0.5 million & $\$ 320$ a year. \\
\hline Bolsa Familia & Brazil & $\begin{array}{l}\text { 2003, replaced } \\
\text { Bolsa Escola, } \\
\text { PETI and Gas } \\
\text { Subsidy }\end{array}$ & Cash & $\begin{array}{l}\text { Households in extreme poverty } \\
\text { and poor households with } \\
\text { children. }\end{array}$ & $\begin{array}{c}8.2 \text { million } \\
\text { households by } \\
\text { December } 2005 \text {. }\end{array}$ & $\begin{array}{l}\text { Households in extreme poverty (per } \\
\text { capita income below US\$22) receive } \\
\mathrm{R} \$ 50 \text { (US\$22) a month plus US } \$ 7 \text { per } \\
\text { child below } 16 \text { years of age up to } \\
\text { three. Households in poverty (income } \\
\text { between } \mathrm{R} \$ 50 \text { and } \mathrm{R} \$ 100 \text { ) receive } \\
\mathrm{R} \$ 15 \text { per child below } 16 \text { age up to } \\
\text { three. }\end{array}$ \\
\hline Chile Solidario & Chile & 2002 & Cash & Households in extreme poverty & 225,000 households & $\begin{array}{l}\text { Equivalent to fixed and variable costs } \\
\text { of water and sewage up to a ceiling, } \\
\text { plus a schooling subsidy. }\end{array}$ \\
\hline $\begin{array}{l}\text { Productive Safety } \\
\text { Net Programme }\end{array}$ & Ethiopia & 2005 & $\begin{array}{l}\text { Cash/Food for } \\
\text { work }\end{array}$ & $\begin{array}{l}\text { Provides cash or food transfers } \\
\text { to chronically food insecure } \\
\text { households. }\end{array}$ & 7.2 million people. & $\begin{array}{l}\text { Cash transfer amounts to around } 30 \\
\text { Birr (around US\$3.30) per person per } \\
\text { month, raised in January } 2008 .\end{array}$ \\
\hline $\begin{array}{l}\text { National Rural } \\
\text { Employment } \\
\text { Scheme }\end{array}$ & India & $\begin{array}{l}\text { Bill approved in } \\
2005\end{array}$ & Cash & $\begin{array}{l}\text { Aimed at every adult living in a } \\
\text { rural area and willing to do the } \\
\text { work. }\end{array}$ & $\begin{array}{l}\text { Expected to support } \\
24 \text { million } \\
\text { households annually. }\end{array}$ & $\begin{array}{l}\text { Wages will be paid in cash or in kind or } \\
\text { both - not less than Rs. } 60 \text { a day } \\
\text { (around US } \$ 1.50 \text { ). }\end{array}$ \\
\hline $\begin{array}{l}\text { Programme of } \\
\text { Advancement } \\
\text { through Health and }\end{array}$ & Jamaica & 2002 & Cash & $\begin{array}{c}\text { Monthly cash benefit to } \\
\text { households with vulnerable } \\
\text { members conditional on school }\end{array}$ & $\begin{array}{l}\text { Target of } 236,000 \\
\text { beneficiary }\end{array}$ & US $\$ 6.20$ per month. \\
\hline
\end{tabular}




\begin{tabular}{|c|c|c|c|c|c|c|}
\hline Education & & & & and health centre attendance. & households. & \\
\hline Pension Scheme & Lesotho & 2004 & Cash & $\begin{array}{l}\text { Unconditional cash transfer to } \\
\text { citizens over } 70 \text { years old. }\end{array}$ & $\begin{array}{l}69,046 \text { direct } \\
\text { beneficiaries. }\end{array}$ & M150 or US $\$ 25$ per month. \\
\hline $\begin{array}{c}\text { Mchinji Social } \\
\text { Cash Transfer Pilot } \\
\text { Scheme }\end{array}$ & Malawi & 2006 & Cash & $\begin{array}{l}\text { Targeted to the ultra poor and } \\
\text { the labour constrained. }\end{array}$ & $\begin{array}{c}\text { By the end of } 2008 \\
12,000 \text { households } \\
\text { will be reached. }\end{array}$ & $\begin{array}{l}\text { Between MK600 and MK1800 (US\$4- } \\
\text { 13) according to household size. Plus } \\
\text { MK200 for children in primary school } \\
\text { and MK400 for those in secondary } \\
\text { school. }\end{array}$ \\
\hline $\begin{array}{l}\text { PROGRESA. } \\
\text { Renamed } \\
\text { OPORTUNIDADE } \\
\text { S in March } 2002 .\end{array}$ & Mexico & 1997 & Cash & $\begin{array}{l}\text { Targeted to poor rural } \\
\text { households using geographical } \\
\text { and then proxy household } \\
\text { means testing. }\end{array}$ & $\begin{array}{l}3.2 \text { million } \\
\text { households in } 2001 \\
\text { (40\% of rural } \\
\text { households, } 3.38 \% \\
\text { of the population). }\end{array}$ & $\begin{array}{l}\text { US\$12.50 per family as consumption } \\
\text { supplement. US\$8-16.50 per child in } \\
\text { primary school per month and } \$ 15.50 \\
\text { on school materials per year. US } \$ 24- \\
30.50 \text { a month for secondary school } \\
\text { and US } \$ 20.50 \text { for materials. Up to } \\
\text { maximum of US } \$ 75 \text { per household per } \\
\text { month. }\end{array}$ \\
\hline $\begin{array}{l}\text { Child Money } \\
\text { Programme }\end{array}$ & Mongolia & 2005 & Cash & $\begin{array}{l}\text { Targeted to the poor in } 2005, \\
\text { made near universal in } 2006 . \\
\text { Paid to households on condition } \\
\text { of children being immunised, not } \\
\text { engaged in hazardous labour } \\
\text { and enrolled. }\end{array}$ & $\begin{array}{l}\text { By the end of } 2005 \text {, } \\
647,500 \text { children } \\
\text { (63\% of total) in } \\
292,400 \text { households. }\end{array}$ & $\begin{array}{l}\text { US\$31 a year. An increase to } \$ 117 \text { a } \\
\text { year was approved in the } 2007 \text { budget. }\end{array}$ \\
\hline Social Pension & South Africa & Early 1990s & Cash & Unconditional old age pension. & $\begin{array}{c}1.9 \text { million } \\
\text { beneficiaries. }\end{array}$ & $\begin{array}{l}\text { Means tested up to maximum of } \$ 75 \\
\text { per month. }\end{array}$ \\
\hline $\begin{array}{l}\text { Child Support } \\
\text { Grant }\end{array}$ & South Africa & 1998 & Cash & Unconditional child allowance. & 8 million children & $\begin{array}{l}\text { Around US\$20 (R160 in 2002)a } \\
\text { month. }\end{array}$ \\
\hline $\begin{array}{c}\text { Pilot cash transfer } \\
\text { scheme Kalomo } \\
\text { district }\end{array}$ & Zambia & 2004 & $\begin{array}{l}\text { Unconditional } \\
\text { cash transfer }\end{array}$ & $\begin{array}{l}\text { Targeted at critically poor } \\
\text { households. }\end{array}$ & $\begin{array}{l}1027 \text { households, } \\
3865 \text { individuals. }\end{array}$ & US\$6 (ZMK 30,000) per month. \\
\hline
\end{tabular}




\section{Social transfers, consumption and investment}

Several studies have observed that receipt of transfers is often associated with a range of household investment in human capital and other productive assets. These findings, which will be explored in more detail below (see Annex 1 listing findings for a wide range of programmes), strongly suggest that in developing countries income transfers focused on those in poverty have effects which go beyond the supplementation of current consumption. Typically, the largest share of transfers is spent on food and services. Improved consumption levels can lead to improved labour productivity. Social transfers are often used to directly support investment in schooling, health care and prevention, livestock and other agricultural assets, and micro-level financial assets, for example. Whether through improvements in nutritions that lead to higher labour productivity, or through direct investment, social transfers have the capacity to support income growth among beneficiary households and their communities. This raises the important issue of whether, and to what extent, social transfer programmes could also contribute to broader growth objectives. The main objective of this Review is to illuminate this issue.

Systematic knowledge of the growth effects of social transfers in developing countries is unfortunately lacking. In fact, one of the aims of this paper is to develop a framework to organise and weigh up the insights and evidence emerging from existing programmes. This basic framework presented below is necessarily a provisional one, which will need to be developed and strengthened as further information and evidence emerges. There are important gaps as well as areas of uncertainty in the information available. There is more discussion on the growth effects of social transfers where household investment is a direct and explicit objective of a programme. In conditional human development transfer programmes, the transfer is expected to lead to improvements in health care and schooling, and these outcomes are assessed directly in the course of monitoring and evaluation activities. There is much less discussion of potential growth effects of transfers where the link to investment is not explicit, and/or monitoring and evaluation processes are weak. Overall, the available literature provides an insufficient basis to support a precise quantification of these effects. A further aim of this paper is to identify ways in which this work could be advanced.

The structure of the report is as follows. Section 2 will develop a framework for assessing the growth effects of social transfers. The objective here is to identify the processes through which transfers influence income growth. Section 3 will organise and present available findings on the growth effects of social transfers, emerging from impact assessment studies. The review will focus on reliable studies based mainly on impact evaluation grounded on household survey data. Section 4 will discuss the implications for social transfer policy, 
especially issues of design and implementation. Section 5 will provide recommendations on appropriate ways of incorporating growth objectives in social transfer programmes.

\section{Explaining why social transfers can have growth effects}

The primary objective of social transfers in developing countries is to reduce poverty and vulnerability, by supplementing the income, and hence purchasing power, of beneficiary households. In line with this objective, the effectiveness of social transfers is commonly measured by the rise in household consumption following the introduction of a programme. Economic growth is seldom an explicit objective of social transfers. At the household level, income growth over time requires investment in human, physical, or financial assets. Investing in children's education, for example, is a sound strategy to improve their future productivity and income. For credit strapped households, this investment requires raising saving and therefore a reduction in current consumption. This presents an apparent paradox, how do consumption subsidies manage to support investment. This is the focal question for this section: Under what circumstances do social transfers, aimed at raising consumption, support growth processes?

The answers we find for this question have important policy implications. The fact that social transfer programmes lack explicit growth objectives reflects a view among policy makers that social transfers are not appropriate policy instruments to deliver growth, compared to trade, investment, and industrial policies for example. The discussion in the paper does not suggest that social transfers can replace trade policies, say, as a means of securing growth. However it does suggest that social transfers are a necessary complement to trade policies in ensuring the opportunities generated by growth reach the poorest and most vulnerable in society. If it can be shown that consumption subsidies can be effective in supporting income growth among the poor, then social transfers are appropriate policy instruments to deliver growth objectives, in combination with other policies. The interesting issue, from a policy perspective, is whether social transfers have growth effects, especially among the poor; and, if these effects can be identified, whether they are sufficiently reliable and significant to be the object of policy.

To approach this question, we need a basic framework for understanding the factors influencing decisions concerning consumption and investment for poor households, and for capturing the linkages existing between transfers, the growth mediating processes they influence, and growth outcomes. This basic framework will help us to organise and assess the main insights and evidence emerging from the available literature. This section builds a basic framework in three main steps. Firstly, we justify why our focus will be primarily on poor households. This is because poor households often face a different set of constraints and opportunities than a representative household. Secondly, we show in the context of poverty traps, an extreme case of differential opportunities, what role social transfers can potentially play in support growth strategies. Thirdly, we discuss how transfers can stimulate growthmediating processes, and lead to growth outcomes. The section which follows from this discussion adds the available evidence to the basic framework. 


\section{A focus on the poor}

In developed countries, discussion of the linkages between social transfers and growth, mainly fuelled by policy concerns regarding the size and cost of the welfare state, has stimulated cross-country empirical studies. These studies seek to explain growth performance across a range of countries, on the basis of variables representing the factors of production (mainly technology, capital, and labour) and variables capturing social expenditure or social transfers. The hypothesis being tested is this: if social expenditures or social transfers are harmful to growth performance, then they will show a negative correlation with growth across a sample of countries. Countries with relatively higher levels of social transfer expenditure will show relatively lower growth. In spite of the considerable resources invested in this approach, no clear conclusions have emerged to date. Some studies find that social transfers facilitate growth, others that they harm growth, and a majority of the studies finds there is no statistically significant correlation between social transfers and growth performance, (Atkinson, 1999; Arjona et al, 2001; Perotti, 1992). Given the scant returns from the estimation of aggregate growth models, and the paucity of reliable data for many developing countries, there is little to recommend following this route to studying the growth effects of transfers in the latter.

\section{Growth effects of social transfers in developed countries: cross-country studies}

Several studies have sought to estimate the correlation existing between public expenditure and growth in developed countries, with a view to determining whether high (low) levels of expenditure are associated with slower (faster) growth. In some of these studies, the growth effects of social security expenditure, and social transfers in particular, have been estimated separately. Some studies find that social transfers have a positive effect on growth, while others find the opposite effect (Atkinson, 1999). Atkinson's review of the available evidence argues for the need to go beyond aggregate models to 'investigate the underlying microeconomic relationships'. A recent OECD study extended the review to 25 studies completed between 1990 and 1997 (Arjona et al, 2001). It finds significant and positive growth effects of 'active' social transfers, those that encourage participation in the labour market by recipients, but no reliable growth effects from 'passive' social transfers, those that simply redistribute purchasing power to specific groups such as the elderly. (Banerjee and Duflo, 2004)

To consider the potential effects of transfers on growth in developing countries we must take a different route. In aggregate growth models, the implicit unit of analysis is the representative agent in the economy. This is unhelpful in the context of our study which focuses on low income households and communities. The findings from a wide range of development literature demonstrates that, for a variety of countries and settings, those in poverty face a different set of prices and opportunities than the better off. This insight emerges, for example, from studies looking into the opportunities for the poor and poorest in credit or asset markets. Credit markets seldom work well for the poorest as financial institutions require some collateral to access loans. Those in greatest poverty are perceived by financial institutions as a bad risk because of their higher likelihood of default, and as a result collateral conditions apply to them in full. However, the poorest seldom have 
the resources to offer collateral. The implication being that poverty qualitatively reduces access to loans. It is considerably costlier for those in poverty to access loans, especially compared to the well off. There are also differential opportunities for asset accumulation by the poor and poorest. The 'lumpiness' of productive assets, for example livestock, machinery or land, undermines the possibility of incremental investment by those in poverty. Social exclusion arising from gender or other factors can produce similar thresholds in access to services. These are examples of situations in which the set of opportunities available to those in poverty is qualitatively different from the set available to the better off. In this context, developing an understanding of the growth effects of transfers requires that we focus on the opportunities available to the poor and poorest households.

\section{Poverty traps and transfers}

Poverty traps are an extreme example of differential opportunities for the poorest, as they bind households into a state of persistent poverty from which escape is especially difficult. A brief discussion on poverty traps will provide an illustration of the limited opportunities available to the poorest, and suggest an important role for transfers in extending them.

The kind of circumstances that make poverty traps possible can be illustrated by considering nutrition and work capacity in a simplified model (Ray, 1998). Take a healthy adult and map the nutritional conditions needed to ensure work capacity. The livelihood of the workers and her family can be represented by the connections existing between current income $\rightarrow$ nutrition $\rightarrow$ work capacity $\rightarrow$ future income. Workers need food to support their work activity, and in turn, their capacity to be productive determines the income they are able to secure with their labour. To simplify matters, we could assume that income can be translated straightforwardly into food, and that work capacity also translates straightforwardly into future income.

We could focus initially on the link between nutrition and work capacity only. We can postulate that the function linking nutrition to work capacity is ' $S$ ' shaped. The ' $S$ ' shape can be explained thus: an adult at rest requires only a basic amount of food to maintain rest metabolism, but work activity demands additional amounts of food to support the energy spent. Starting from very low income/nutrition, additional amounts of food do not raise work capacity significantly until the nutritional requirements of rest metabolism have been met in full. Above this level additional nutrition raises work capacity rapidly, but at some further point this effect wears off. Excess nutrition can be stored to meet possible future deficits but, beyond some point, additional amounts of food no longer improve work capacity and could possibly reduce it. Figure 1 below shows this ' $S$ ' shaped function. The broken line is at the $45^{\circ}$ angle, so the points on that line represent conditions in which current income generates the same future income (through the impact of nutrition on work activity). Points above and to the left of the broken line are typically 'growth' points, where future income will be higher than current income. Points below the broken line and to the right represent conditions in which future income will be lower than current income and reflect a decline in living standards.

Starting from 0 , we can see that the curve is initially relatively flat until the nutritional requirements for rest metabolism are met. The curve then rises steeply as additional 
amounts of food raise work capacity, but at some point this increase levels off as excess amounts of food cease to contribute to work capacity. Above point $B$, current income, and hence nutrition, leads to a 'growth' cycle, but below this point current income is not sufficient to generate the same future income and a cycle of decline sets in. This is what is meant by a poverty trap.

\section{Figure 2 Nutrition and work capacity}

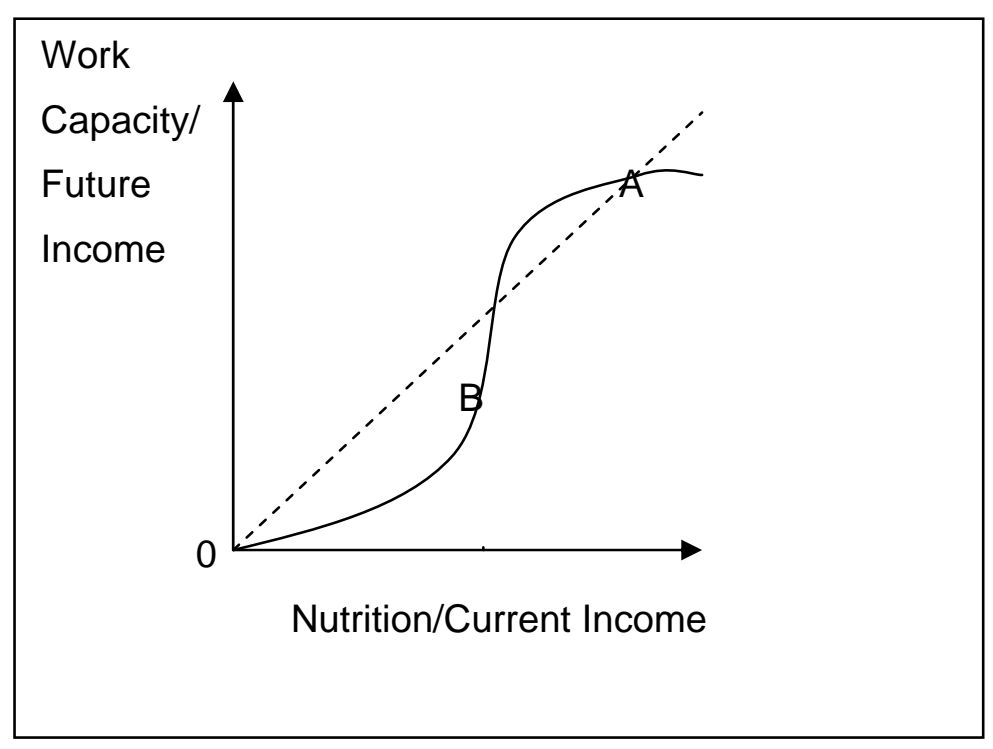

Of course, poverty traps are an extreme case of the poor facing a different set of economic opportunities than the non-poor, but we are interested here in the insight it provides as to the circumstances faced by the poor, and the potential role of social transfers in overcoming them. For workers located in the segment of the solid line below $B$, a social transfer that can supplement their nutrition so that they can reach point B on this line would effectively shift them onto a growth path. Having sufficient food to be productive, workers could then secure higher levels of income, and therefore future nutrition. A transfer could lift workers out of their poverty trap, and ensure they and their households enter into a growth cycle.

Although the example provided focuses on nutrition, the same insight applies to a number of areas. The difficulties faced by the poor and poorest to access credit or to accumulate assets could be represented in similar ways to Figure 1. Poor households lack the income and resources to provide the collateral required by credit agencies. They are unable to invest in human capital or other productive assets. The same applies to rural households requiring a minimum level of assets, e.g. livestock, agricultural inputs, to move beyond subsistence agriculture. In both cases, social transfers could help poor households exit their poverty trap and embark on a growth cycle of investment and raised productivity.

Although the discussion has focused on markets, and economic opportunity, there are important implications from the poverty traps perspective which apply to household dynamics too. It will be useful to draw these implications briefly here. Returning to Figure 1, we could now focus on the household being represented there. Assume a household with two adults with one adult in work. Further assume that she receives current income consistent with point $A$ in the Figure. At that point work income is sufficient to guarantee work capacity, at a level 
which is sustainable (current income could support work capacity sufficient to ensure the same level of future income). But with two adults in the household, some sharing of food will be required. If income $A$ is divided equally between them, work capacity for the working adult will necessarily fall at some point below $B$. This is problematic because at any point below $B$ on the current income axis, income is insufficient to support work capacity needed to secure adequate future income. In fact, this is a poverty trap because insufficient work capacity generates low future income which in turn generates even lower work capacity, and so on. Under these circumstances, those in poverty may have to think and act differently to the better off. In this particular case, an egalitarian household is threatened with a cycle of poverty and deprivation.

In sum, those in poverty could well face a different set of economic opportunities than the better off, and might be compelled to respond in ways which restrict their future well-being and values. Poverty traps are extreme cases in which these conditions apply. Social transfers could play a vital role in enhancing the set of opportunities available to those in poverty and enabling households to find growth pathways. This is also helpful as an explanation of the circumstances under which consumption based transfers can support growth. This discussion provides a basic insight into the framework needed to study the growth effects of social transfers. In the next section we identify the key elements of this framework.

\section{A basic framework: growth-mediating processes and outcomes}

This section provides a basic framework to identify and organise the main effects of social transfers on growth. Chart 1 below summarises the main linkages, and the text below discusses these briefly.

The main conclusion from the previous discussion is that our focus should be primarily on the extent to which social transfers have observable growth effects on those in poverty. Income transfers are intended to raise household consumption directly, but they could also act to stimulate household investment, which results in growth of household income over time. As the previous section demonstrated, the growth effects of transfers will be significant in situations in which the transfer shifts poorest households onto a growth cycle, by lifting restrictions on investment by the poorest.

\section{Mozambique: Social assistance and productive capacity}

The Government of Mozambique is engaged in developing a national social protection strategy focused on strengthening and extending a range of social transfers and services aimed at poverty reduction. Existing programmes have developed in a piecemeal fashion targeting important deficits among poor and vulnerable groups, with limited resources and support. A food subsidy programme provides a transfer in cash to highly vulnerable households headed by older people who are unable to work, and including many Orphans and Vulnerable Children as well as people with disabilities and chronic illness. The subsidy amount varies depending on household size but has had limited impact in part because 60 
percent of its beneficiaries are registered as single person households, and in part because the transfers are set at a very low level. Other social protection interventions focus on basic services and infrastructure. Linking up these interventions could help deliver improved integrated support for those in poverty, emphasising productive and protective objectives. A stronger evidence base is currently being collected and studied to provide a firm foundation for an emerging social protection strategy.

A basic framework for tracing the growth effects of social transfers would need to identify the growth-mediating processes through which the transfers lead to investment and growth at the household level. Three such processes have been identified in the theoretical and empirical literature. They are:

- The extent to which social transfers are able to lift credit constraints. As has been noted, credit markets often exclude the poor and poorest, but regular and reliable transfers can help overcome barriers in access to credit. This can work in two ways, through enhancing the saving capacity of poor households or through facilitating improved access to credit.

- The extent to which social transfers provide greater certainty and security in consumption and investment outcomes. Poor households have fewer buffers to protect themselves and their assets against hazards. Insurance services seldom reach the poor and poorest. Uncertainty and insecurity make investment especially risky and therefore undermine income growth. Transfers can provide increased security and in the process make investment possible.

- The extent to which social transfers facilitate improved household resource allocation and dynamics. Household resources allocation can be less than optimal if povertyrelated credit and liquidity constraints prevent resource re-allocation. Service userfees, or migration costs, are relevant examples. Social transfers can help overcome investment restrictions arising from intra-household dynamics. Social transfers channelled through the mother or carer can ensure greater investment in children's education and health.

The next section provides a detailed discussion of these growth-mediating processes and reviews the evidence on them emerging from studies of social transfers. The effectiveness of social transfers in stimulating household investment and growth can be measured by their outcomes as regards human development investment, asset accumulation and labour supply. These outcomes are linked to growth mediating processes influenced by social transfers as noted above.

First, human development investment constitutes a primary objective for a good number of social transfer programmes. This is particularly the case for programmes focused on breaking the intergenerational persistence of poverty, such as Bolsa Familia in Brazil. The emphasis on household investment, in schooling or primary health utilisation, is apparent from the conditional nature of the transfers. The growth effects of social transfers can be assessed on the basis of measured human development outcomes. 
Second, in some cases, social transfer programmes explicitly aim to facilitate productive or financial asset accumulation, as in Bangladesh's Challenging the Frontiers of Poverty Reduction/Targeting the Ultra Poor programme. Here the growth effects of social transfers can be measured in the context of asset protection and accumulation by beneficiary households. The expectation is that social transfers will have positive effects on these outcomes.

Third, the expectations associated with the impact of social transfers on labour supply in beneficiary households are mixed. To the extent that social transfers raise the income of beneficiary households. This could have negative or positive effects on their employment. Social transfers that include inactivity tests of eligibility, as most pension programmes in developed countries do, may restrict labour supply. On the other hand, where transfers improve productive capacity, as in the nutrition discussion in the previous section, labour supply may increase among beneficiary households following receipt of transfers.

Separately, the framework should consider the impact of social transfers on incentives to work and save among non-beneficiary households as a second order issue. Where social transfers are financed out of tax revenues, the imposition of taxes on non-beneficiaries may influence their decisions on saving or working. The size and type of the taxation required will largely determine the strength of these effects. There is a large literature focused on the disincentives to work arising from poorly designed social transfer schemes in developed countries that are financed out of payroll taxes. They have a direct influence on the labour supply and savings of workers. These effects are likely to be significantly smaller in developing countries, where the size of social transfer programmes is smaller by an order of magnitude, and where income and payroll taxes contribute only a small share of government revenues. Nonetheless it is important to consider the importance of the growth effects of social transfers on non-beneficiaries.

Finally, it is worth noting potential positive external effects of social transfers on nonbeneficiaries, through the presence of demand-side multipliers. These could be more significant in smaller, largely self-contained, local economies. Evidence is emerging from Africa in particular of social transfers stimulating the emergence of local markets. Mozambique's GAPVU programme led to the growth of street traders around transferdispensing offices, while in Namibia many grocery stores arose in even the smallest villages in response to the increased demand generated by the social pension programme.

In summary, the main points of the section are:

- To begin to understand the potential impact of social transfers on growth it is important to focus on the poor.

- The poor face a different set of opportunities than the better off. At its most extreme, this can situate them in poverty traps. 
- Social transfers can play a vital role in enhancing the opportunities available to the poor, helping to move them onto a growth cycle.

- Social transfers facilitate growth through three key processes: by lifting credit constraints, by providing greater certainty and security and by facilitating improved household resource allocation and dynamics.

- There are also effects on non-beneficiaries, notably potentially negative effects on their incentives to work and save, but also positively through demand-side multipliers. 
Figure 3 Growth effects of transfers: A basic framework

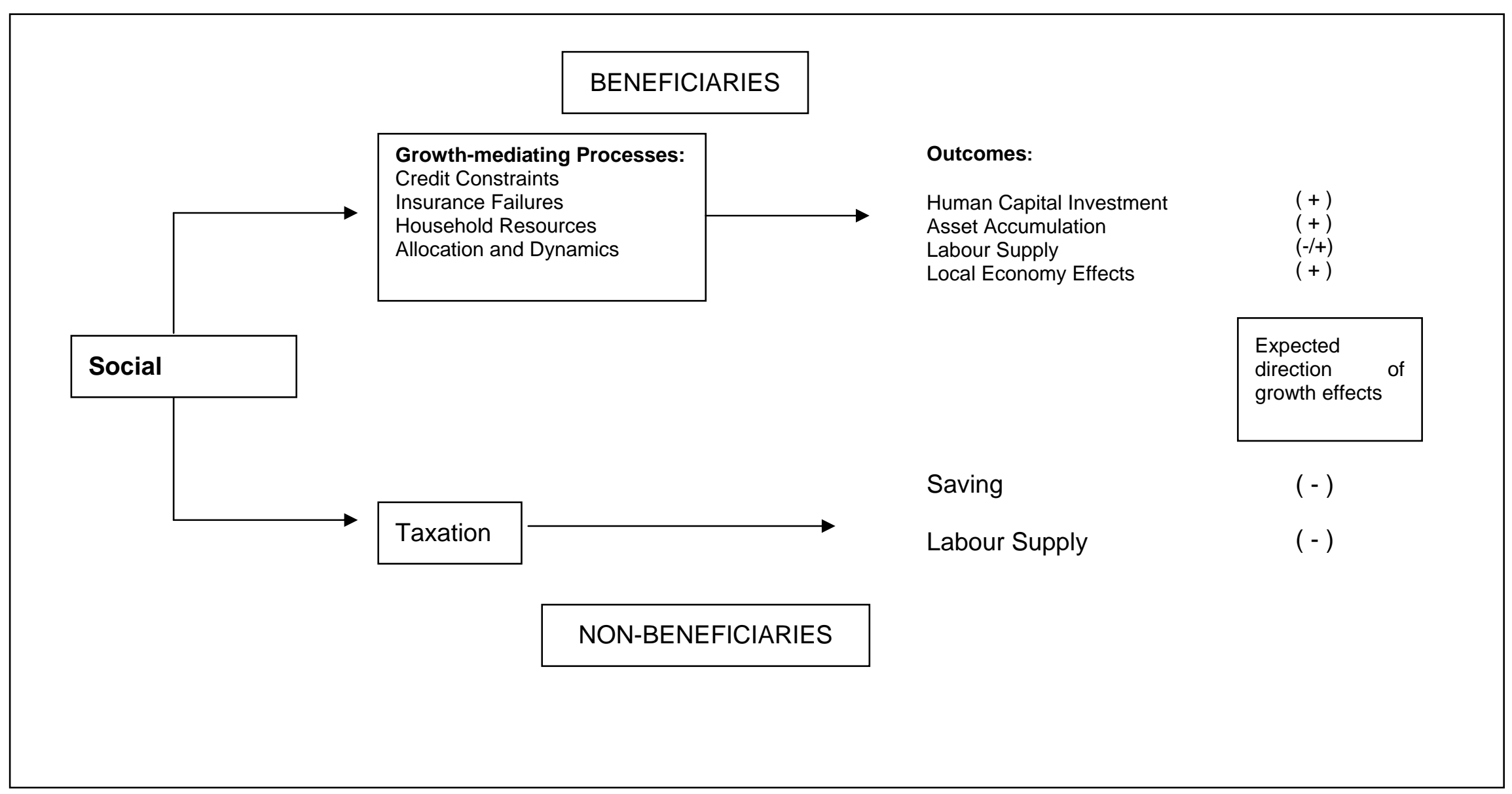




\section{Social transfers and growth-mediating processes}

In this section we track the effects of social transfers on the capacity of poor households to engage in productive investment, that is growth-mediating processes. We focus on three areas in which social transfers are expected to lift restrictions on household investment: credit constraints, insurance failures, household resource allocation and dynamics (Banerjee and Duflo, 2004).

\section{Alleviating credit constraints}

As was noted above, those in poverty face binding credit constraints. They have difficulties in providing collateral to financial institutions to secure loans, especially as the urgency of their consumption needs makes them more likely to default. The development of micro-credit institutions in developing countries is a policy response to the well documented barriers to access credit. However, the literature on microfinance and micro-credit institutions also documents the difficulties involved in reaching the poorest households. There are two ways in which social transfers could help lift credit constraints for poor and poorest households. Firstly, social transfers, providing they are regular and reliable, can encourage small scale saving and investment providing another route to lowering credit constraints. Secondly, social transfers could prove more effective, in combination with other interventions, in enabling access to credit. This section reviews the available evidence. There are indications across a variety of social transfer programmes, in middle and low income countries, that beneficiaries are able to save and invest a fraction of their income following the receipt of transfers, and also that access to credit can be facilitated by the transfer. The evidence is largely qualitative, but has been carefully measured in some programmes.

Examples where social transfers themselves have encouraged saving and investment include Bolivia and Mexico. In Bolivia, a social pension BONOSOL is paid once a year to persons aged 65 and over. At US\$246, it is a significant injection of liquidity for rural farmers who have land but no cash or credit to purchase seeds and other agricultural inputs. A study has estimated that among pension beneficiaries in rural areas, overall consumption rises by twice the amount of the benefit, suggesting that improved household production was facilitated by the transfer, (Martinez, 2007). The effect is observed only among rural households with land, and is stronger for goods which are typically produced by these households, such as dairy produce, meat and vegetables. Similarly, studies have observed a rise in investment by beneficiary households under PROGRESA compared to nonbeneficiaries. Gertler et al. estimates that, on average, around 12 percent of transfers to beneficiaries were invested in productive assets (Gertler et al 2005). And Sadoulet, de Janvry and Davis (2001) who compared transfers under PROGRESA and PROCAMPO, a human development conditional transfer programme and a productive transfer to owners of small farms respectively, find that the latter had income multipliers of around 1.5 to 2.6 . The main effect of PROGRESA was instead on human capital investment. 
Beneficiary households of Bolivia's BONOSOL programme in poor rural areas experienced an average increase in food consumption of almost $165 \%$ of the value of the transfer. This was achieved through the investment of part of the transfers in much needed agricultural inputs. ${ }^{12}$

Examples where social transfers, combined with other interventions have improved access to credit include Brazil and Bangladesh. In Brazil, a social pension named 'Prêvidencia Rural' was introduced to cover informal workers and their households. The regularity of the pension benefit enables pension beneficiaries to access loans from banks, by showing the magnetic card which is used by them to collect their pensions (Schwarzer, 2000). A study of the impact of the pension on the households of recipients observed a high incidence of investment in productive capital (Delgado and Cardoso, 2000). Social transfers can also help lift credit constraints for poorest households as a component of a package of interventions including micro-credit. Direct evidence of improved access to credit has been provided for the Targeting the Ultra Poor programme in Bangladesh. This programme provides a mix of transfers in kind and cash to households in extreme poverty in preparation for more standard micro-credit programmes after 18 months. A sample of selected beneficiary households was compared with a sample of non-selected households, the latter slightly better off but still poor, in 2002 at the start of the programme and in 2005 (Rabbani et al 2006). The comparison suggests that beneficiary households showed significant improvements over time in the incidence and size of loans they held, in part explained by their access to the micro-credit component of the Programme. It is also possible to observe a shift in the motivation for credit among selected households. In 2002, credit is primarily a means of smoothing out consumption, but in 2005 the dominant motivation is investment in productive assets. Moreover, credit access for beneficiary households both over time and in relation to non-beneficiary households shows a significant improvement.

\section{Bangladesh: The Chars Livelihood Programme (CLP), asset accumulation and environmental hazards}

Poverty reduction policies in Bangladesh traditionally focused on food aid, but more recently their focus has moved on to asset accumulation, especially through micro-credit and finance, delivered through NGOs. This approach has proved effective for moderately poor household, but less effective for poorest households, described in Bangladesh as the 'ultra poor'. BRAC's Challenging the Frontiers of Poverty Reduction - Targeting the Ultra Poor aimed to reach poorest households. Another programme focused on the poorest recently implemented is the Chars Livelihood Programme (CLP). The chars are sandy islands and low-lying floodprone areas in Bangladesh. The CLP includes a range of interventions aimed to improve infrastructure in what is a particularly difficult environment, help asset building and protection among the poorest, encourage social development, provide community-based social protection, and promote growth in agriculture and other sectors, through micro-finance and livestock services. A feature of this programme is its focus on environmental hazards. The 
Programme was inaugurated in August 2004. These two programmes, and others that are similar, will help clarify what interventions are effective in reaching the poorest in Bangladesh, and especially the mix, timing, and sequencing of protection and asset accumulation interventions.

The findings reviewed here provide important insights into the way in which transfers can be effective in lifting credit constraints, and lead to productive investment and asset accumulation among beneficiary households. Transfers, providing they are regular and reliable, can act as an alternative means for those in poverty to finance productive investment and can enhance access to credit by removing the need for collateral, as in the case of Brazil. Transfers can also be an important component of micro-credit programmes addressed at the poorest as in Bangladesh. Whilst providing important insights, the evidence reviewed is not systematic across all social transfers. In some transfer programmes, especially pure income transfers such as social pensions or human development transfer programmes, access to credit is simply a by-product of the income transfer, and not an explicit objective. The evaluation of these programmes may not focus on this issue. The capacity of social transfers to help lift credit constraints is likely to vary across programmes, target groups, and environments. These effects are stronger where credit constraints are directly targeted, as in Bangladesh. Broadly, transfers have greater effects among rural households with deficits in complementary 'productive' assets (e.g. inputs, labour). These studies also indicate that transfers can support growth in household production and therefore have multiplier effects. It is harder to observe these effects in urban settings. These effects have been observed in both middle-income and low-income countries.

\section{Improving security}

There is considerable evidence that poor households adopt a range of strategies to protect their consumption and assets from the impact of hazards. Security is important to those in poverty, especially in the context of the capacity of the poor to invest. Insecure and precarious livelihoods are bound to limit investment by poor households. The gaps in effective policy instruments in this area are well recognised. The theoretical and empirical literature finds that insurance markets seldom reach those in poverty, with the implication that they remain insufficiently protected (Dercon, 2005; Jalan and Ravallion, 1999). Insufficient insurance protection has damaging effects on the ability of the poor and their households to exit poverty and benefit from economic opportunity. Insecurity leads to inefficient use of resources by those in poverty (Barrientos, 2007), for example by forcing rural poor households to opt for low-risk/low-return crops and production methods (Morduch, 1995) which reduces growth opportunities. Insecurity also forces poor households to holding liquid but less productive assets (Dercon, 2003). It also leads to distortions in inter-temporal resource allocation, forcing a focus on current consumption in preference to investment. This is typically the case when households withdraw children from school or 'economise' on health care in response to crises. In the absence of security, responding to short term shocks can lead to poverty persistence. 
Regular and reliable social transfers can improve household security, firstly through supplementing household income, and therefore improving the impact of consumption shocks; and secondly through integrating insurance features protecting consumption, assets and investment. Social transfers can also improve the adverse effects of policy change, agricultural liberalisation for example.

Social transfers can be designed so as to improve insurance protection, enabling recipients to engage in higher-risk, higher-return investment. For example, in Maharashtra, India, the insurance provided under the Employment Guarantee Scheme enabled farmers to plant high-yield crops, rather than the low-yield, drought-resistant varieties used elsewhere. ${ }^{1}$

Theory suggests that incorporating insurance components in social transfers can help protect households from shocks or crises, thus ensuring a better use of household resources, and lift inter-temporal distortions on human and productive capital investment. However, few social transfers have explicit insurance components. Some variants of public works could be an important exception to this generalisation. The National Rural Employment Guarantee Scheme in India, for example, provides entitlement to up to 100 work days for unemployed rural households, on demand. The design of the employment guarantee is specifically aimed at smoothing consumption among rural households (Kannan, 2006). The Unemployed Heads of Households programme in Argentina was crucial in supporting households affected by the 2001 crisis in Argentina. By contrast, social pensions or human capital cash transfer programmes have no explicit insurance component aside from the buffer provided by the supplementary income transferred. This is because transfers are fixed in level, and are unchanged through shocks or crises (Sadoulet et al 2004). Human development conditional social transfer programmes in Latin America have at best indirect insurance components, for example through the enforcement of schooling conditionalities which are sustained through crises. This is an important deficiency of these types of social transfers in both middle income and low income countries.

\section{Improving household resource allocation and dynamics}

Household dynamics is an important factor in determining the capacity of poor households to access economic opportunity. Household decisions, especially as regards the allocation of their resources, are central. Gender differentials in human capital accumulation could be explained, inter alia, by unequal bargaining power within the household. Udry suggests this perspective could also apply to productive investment (Udry, 1996). He finds that differentials in yields in men's and women's plots in Burkina Faso are accounted for by differences in input intensity, especially labour and fertilizers. These differences could, in turn, be explained by women's concerns about having their plots and yields expropriated by their husbands. Child labour and schooling are also the outcome of household resource allocation decision making, with marked gender differential. The issue here is that decisions about allocation of time and effort made within the household, often reflecting unequal bargaining influence, can generate inefficiencies. These in turn could become an important impediment to investment and income growth among the poor. 
Child labour is an important factor in the transmission of poverty from one generation to the next. Social transfers have been shown to help break this cycle by reducing the incidence of child labour. In Mexico, the programme reduced the probability of working among those aged 8 to 17 by 10-14 percent. In Brazil, the PETI programme was found to reduce the probability of children working by 4-7 percent in Pernambuco, almost 13 percent in Sergipe and nearly 26 percent in Bahia. It also reduced the probability of children working in higher risk activities (Rawlings and Rubio, 2003).

There is an emerging literature looking at the impact of transfers on intra-household resource allocation and dynamics, with implications for income growth among those in poverty. In human development social transfers, it is common that transfers are paid to the mother, in the expectation that children stand to benefit more directly if it is the mother who receives it. An interesting issue is whether this modality of transfer payment has any effect on intrahousehold resource allocation, especially in the context of bargaining models suggesting that household decision making is strongly influenced by relative shares of income contributed by different household members (Haddad et al 1997). Studies of the impact of PROGRESA transfers on patterns of consumption in Mexico observe a shift in consumption towards children-related goods and services (Rubalcava et al 2002). This finding could be interpreted as supporting the view that transfers are capable of effecting changes in intra-household resource allocation.

A related issue is whether transfers encourage changes in household labour allocation, especially through migration. This point will be discussed below in the context of the impact of grants on labour supply in South Africa, but it is worth noting that studies on PROGRESA reveal some impact of transfers on domestic and international migration (Angelucci and De Giorgi, 2006; Stecklov et al, 2003). The migration effects on income growth among poor households are hard to define with certainty. It is not possible, therefore, to predict with certainty the net growth effects of migration facilitated by transfers.

The available evidence is far from systematic, although it is likely that the impact of transfers on household resource allocation is significant enough, in both low and middle income countries. The influence of social transfers on household resource allocation has not been sufficiently well researched, and it is in fact approached as a by product of other, more direct effects. It can be argued that changes in household allocation and dynamics have the potential to make a large and long term contribution to poverty eradication and prevention. Further research is needed to identify these effects with greater precision and certainty.

\section{Social transfers and micro-level growth outcomes}

This section reviews the evidence on the growth outcomes of social transfers (Annex 1 contains summary information on the studies/programmes reviewed here).

\section{Improvements in human development}

There is strong evidence demonstrating that conditional social transfer programmes deliver large improvements in school enrolment attendance among the poorest beneficiaries. Many schemes explicitly target schooling through conditionalities. This is common in programmes 
in Latin America, but also in Bangladesh. The transfers are made conditional on school age children attending school. In PROGRESA/OPORTUNIDADES, the design of the transfer strengthens the incentives for household investment in girls' schooling at secondary level, by raising the transfers for them. This programme has ensured high school attendance for girls in rural areas. The Latin American programmes also ensure primary health care utilisation through conditionalities. PROGRESA/ OPORTUNIDADES has been very successful in achieving higher rates of utilisation and improved health status among beneficiaries (Skoufias, 2001).

The evidence on the capacity of social transfers to facilitate investment in human development is not limited to transfer programmes targeting human development or children. Studies on the impact of social pension receipt in South Africa and Brazil, for example, find that households with a pension beneficiary have higher enrolment rates among children of school age and improved health status (Carvalho, 2000; Case, 2001; Duflo, 2003). It also applies in low income countries, although the effects are strongly mediated by supply side conditions in these countries. In order to raise educational and health service usage in low income countries, it must be ensured that they have the capacity to deal with the growth in service demand. For example, the value of increasing the years of education that a child receives is muted if there is a simultaneous decline in the standard of the schooling. In order to overcome this, some transfer schemes that are conditional on school enrolment include a small transfer to the school for each beneficiary child. If the full growth gains of social transfer schemes are to be realised, complementary policies implemented alongside such programmes may be necessary to ensure that services do not decline in standards due to increased demand.

\section{Figure 4}

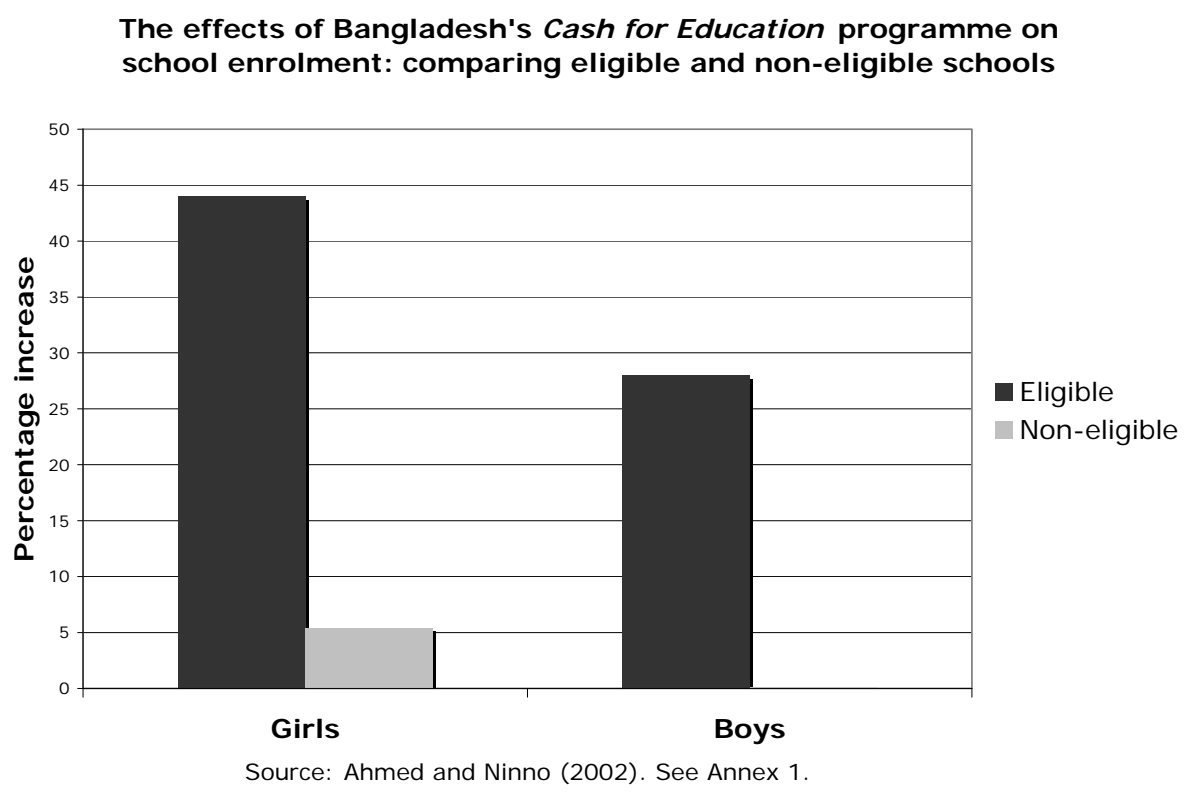




\section{Figure 5}

The Effects of Familias en Acción in Columbia on schooling and consumption

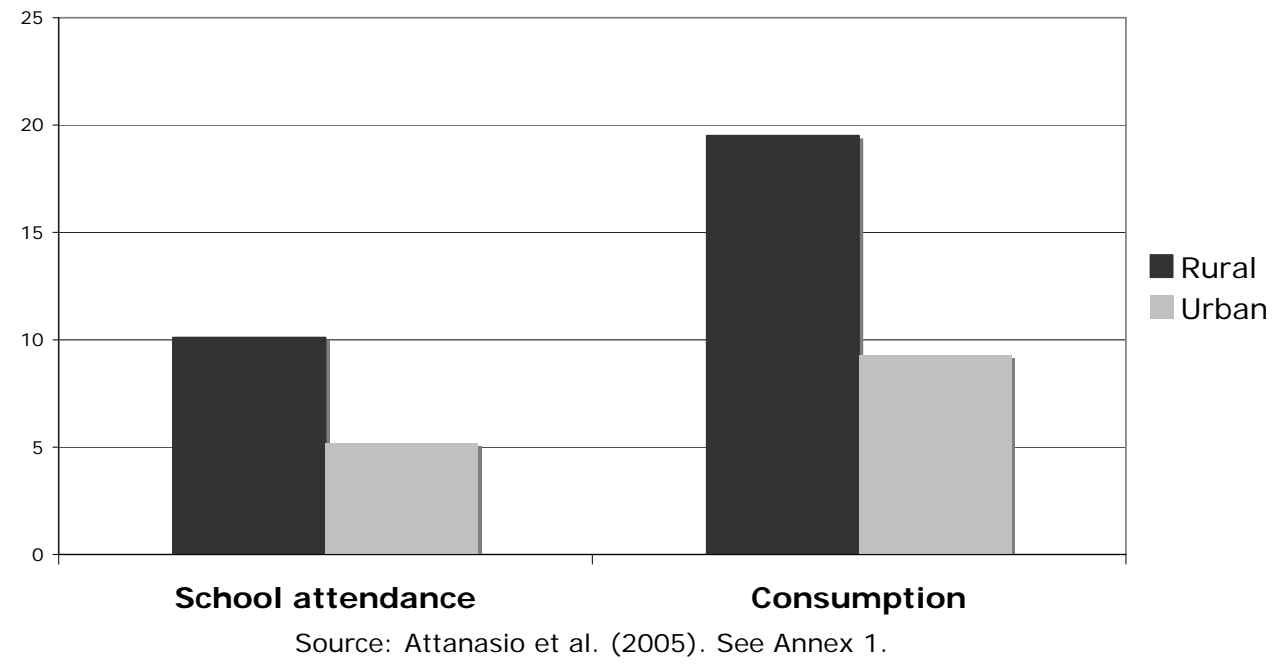

Strengthening investment in human capital is expected to raise the future productive capacity of children. It has been estimated that the improvements in schooling of children in PROGRESA beneficiary households will translate into 0.65 of a year extra by the time they complete their education, and that for girls the improvement in completed years of education will be 0.72 of a year. Given the strong correlation between years of schooling and labour market earnings, explained by market rewards to increased productivity, it is to be expected that transfers will contribute to growth and productivity in Mexico. It is, of course, too early for the actual effects to be observed.

\section{Brazil: Bolsa Familia and poverty reduction in a low growth context}

Bolsa Familia developed out of the integration of several transfer programmes targeting poor households in Brazil: Bolsa Escola, PETI (a programmes for the eradication of child labour), and food and gas subsidy programmes. Bolsa Familia is an integrated cash transfer scheme targeted on the poorest in Brazil, and now reaches around 12 million households. The programme includes conditionalities on schooling for households with children of school age, and it is intended to have an impact on intergenerational poverty persistence in Brazil. It is one of the many programmes in Brazil addressing the needs of poor and vulnerable households, but the largest and most important and has become a flagship for the social policies of President Lula's government, who has recently extended the programme to families with children aged up to 17 . The programme and its components have been identified as key to the reduction of poverty in Brazil against a context of low growth 
performance in the macroeconomy. Bolsa Familia is thought to have contributed to the improvement in the growth performance of rural areas. It enjoys wide political support in the country. Aside from its emphasis on human capital, policy discussion has focused on whether Bolsa Familia is sufficiently well integrated with active labour market policies and micro-credit programmes, considered to be important in generating sustainable and long term escape from poverty among beneficiary households.

\section{Labour supply effects}

Standard economics predicts a decline in labour supply among beneficiary households as a response to the transfer. In as much as households value activities outside paid work, a rise in income is likely to lead to rising demand for all valuable goods, including non-work activities. Hence, a concern with minimising labour supply disincentives has dominated discussions on the optimal design of transfers in developed countries, and has informed policy discussions around welfare reform. In the USA, for example, labour supply conditions apply to the majority of social assistance transfers to non-pensioner households (Moffitt, 2002).

In developing countries, studies have demonstrated that transfers have effects upon labour supply, but that these effects are broadly positive. In some transfer programmes, especially those focused on human capital investment, a reduction in the labour supply of school age children of is an intended outcome of programmes requiring school attendance. The success of these programmes in reducing child labour has been mixed. Given that children's time could be split into schooling, working and other activities, education subsidies providing incentives for schooling may not, by themselves, result in a proportionate reduction in the incidence of child labour. Impact assessments of Bangladesh's Food for Education programme suggest that the reduction in child labour time was less than proportionate to the rise in schooling, and in Mexico's PROGRESA the evidence of a rise in enrolment and attendance from beneficiary children is stronger and more compelling than evidence that education subsidies reduced child labour (Ahmed and del Ninno, 2002; Cardoso and Portela Souza, 2003). The success of PETI in reducing child labour in Brazil was in large measure due to the requirement that children from beneficiary households spend time in after-school activities (Yap et al 2002). Imposing conditionalities on beneficiary households can strengthen incentives for school enrolment and attendance arising from income transfers. The impact of a reduction in child labour could be significant as regards poverty and productivity.

There is also evidence that transfers targeted at older people are likely to reduce their labour supply even in the absence of inactivity tests as a requirement of eligibility. Labour force participation rates for those eligible to receive a pension are very low in South Africa, and decline rapidly when individuals reach the age of pension entitlement (Lam et al 2004). This is to be expected, as the combination of the generosity of the pension benefit and the means test provide strong incentives for withdrawal from the labour market. 
The predicted adverse effects of social transfers on labour supply are not observed in many developing countries because of offsetting factors. Notably, transfers can facilitate migration, encourage additional labour supply from other household members, and reduce the incidence of days in which recipients are unable to work due to ill health.

Given a high incidence of co-residence of pensioners and their extended households in developing countries, and evidence of widespread pension income sharing, it is of some interest whether labour supply effects of social assistance can also be observed among nonpensioners. This has been investigated in some detail in South Africa. Bertrand et al. (2003) suggest that the effects of pension income on hours of work and employment of 15-50 year olds co-residing with pension beneficiaries in South Africa are significant. Using 1993 crosssectional data from three generation African households, they estimate that 15-50 year old co-residents with a pension eligible person undertake on average 6.4 fewer hours of work and have a 4.3 percent lower probability of employment. They also find that the labour supply effect is strongly significant among 15-50 year old males, but not significant among females. Critically, however, this study samples co-residents only and misses out non-resident household members. Posel et al. note that a high proportion of household members of working age migrate to urban centres in search of work - as many as 30 percent of rural households in South Africa have a migrant. Replicating the work of Bertrand et al. but now including migrant household members, Posel et al. (2004) find that the negative association between pension receipt and labour supply in that study becomes positive, and conclude that 15-50 year old individual members of a household with a pension eligible person have a 3.2 percent higher probability of employment. Disaggregating by gender they find no significant effect associated with pension income received by male pensioners on labour supply of adult household members, but a strong and positive effect when the pension recipient is female. They suggest that pension income received by women is particularly important for rural households "not only because it helps prime-age women overcome income constraints to migration, but also because it makes it possible for grandmothers to support grandchildren" (p.24). A recent study has confirmed this finding with longitudinal data helping track household changes around pension receipt (Ardington et al 2007).

Labour supply responses from beneficiary households to social transfers have been studied for a variety of countries and programmes including Brazil, Mexico, South Africa, Ethiopia, and Bangladesh, and the findings from this literature are robust. Overall, the findings could be summarised as follows. Firstly, an increase in unearned income leads to a reduction in the labour supply of children and older people, especially where education subsidies or pensions target these groups specifically. The effects are stronger where social assistance programmes include schooling conditionalities for children or inactivity tests on older people. Secondly, the reduction in labour supply from these groups is often compensated for by changes in the labour supply of other household members. In the case of PROGRESA, a small reduction in child labour appears to have been compensated by an increase in the labour supply of adults, but otherwise adult labour remained unaffected by the income transfers (Skoufias, 2001) It should be noted that to the extent that social transfers lift credit and care constraints, these could work to encourage additional labour supply from other household members. In these circumstances, the impact of social transfers on productivity 
and growth could well be positive. In sum, there is scant evidence that social transfers have negative labour supply effects on beneficiaries.

\section{Local economy effects}

At the local economy level, social transfers have the capacity to counter constraints on productivity and growth. In areas with high poverty incidence, household income growth can be constrained by community level factors, such as the absence of adequate infrastructure or the scarcity of liquidity and local trade. Public works programmes (social transfers conditional on labour supply) could in principle have an impact on both these factors, by transferring income to households and thus enhancing liquidity and upgrading available infrastructure. In practice, the assessment of such programmes has on the whole been very mixed, many public works programmes transfer only a fraction of their budget to beneficiary households due to the cost of inputs, equipment, and technical advice; and in some cases the value of the newly created infrastructure is marginal. Social transfers can also improve liquidity and trade at the local economy level by stimulating effective demand. This underlines the potential importance of positive externalities. The point is that transfers could have effects beyond the direct beneficiaries, and therefore generate the kind of externalities that could impact on income growth in the local economy.

Only a handful of studies have addressed this question. This is in part because few social transfers have explicit growth objectives and therefore evaluations tend to ignore these effects. Few studies have tackled the local economy effects of social transfers. Studies assessing the impact of public works programmes find that their impact at the community level depends to an important extent on programme design, especially the level and periodicity of the transfer (Mc Cord, 2007) In the context of direct income transfer programmes, existing studies suggest social transfers could generate multiplier effects, especially in poor rural areas. Evidence on multiplier effects from social transfers must be considered with great care. Multiplier effects from social transfers are usually identified in the context of the assets and consumption of beneficiaries, rather than their communities as a whole. Two studies on PROGRESA have observed an increase in consumption and productive assets among non-beneficiary households in treatment areas, compared to nonbeneficiaries in control areas (Angelucci and De Giorgi, 2006; Barrientos and SabatesWheeler, 2007)). This can be interpreted as reflecting local economy effects, and applies more strongly to non-beneficiary households with low asset levels at the start of the programme. The evidence base for the presence of local economic effects is at present very 'thin', as few studies on this issue are available. Impact evaluation studies normally focus on the impact of programmes on beneficiaries, and disregard wider effects. This is an important area for further research.

One aspect that could well turn out to be significant in the context of social transfers concerns potential 'demonstration effects' and community development effects. These are beginning to be examined more systematically. Demonstration effects could be responsible for observed increases in health care utilisation by non-beneficiary households in 
PROGRESA (Handa et al, 2000). There is only limited information on the impact of transfers on community institutions and action, but research is underway in several countries. These can be important in lifting the constraints on local economy growth in areas with high poverty incidence.

\section{Saving}

There is very little evidence that transfer recipients reduce their saving in response to the transfer. If anything, the reverse situation applies. Across a range of transfer programmes, in low and middle income countries, studies indicate that an important proportion of beneficiary households save a small fraction of the transfer. It is difficult to identify reliably whether this saving is a direct consequence of the transfer, or whether it involves a reorganisation of household finances following receipt of the transfer. There are also important knowledge gaps as regards the motivation behind this saving. Saving could be motivated by the need to finance lumpy consumption, by a desire to accumulate assets in a context where credit is hard to access, or as insurance. Supporting evidence for all three can be found in the available studies, but health appears to be a dominant factor in insurance motivated saving. Overall, the evidence does not show a reduction in household saving among beneficiaries following receipt of the transfer.

With regards to the potential impact of transfers on saving among the population as a whole, the literature is scarce for developing countries. Social transfers could have effects on aggregate saving in a context where expectations concerning transfers could diminish incentives for saving in existing social insurance schemes. In Brazil, for example, there is concern regarding the possible disincentive effects of social pensions on social insurance contributions (Bonturi, 2002; Clements, 1997) This is directly related to the design of entitlement requirements and transfer levels. The two social pensions in Brazil, the 'Prêvidencia Rural' available to informal workers and the Beneficio de Prestaçao Continuada (BPC) available to older people across rural and urban areas, have, together with all welfare transfers, a floor equivalent to the minimum wage. This is also the minimum guaranteed pension in social insurance schemes. Because around 60 percent of social insurance pensioners receive only this guaranteed minimum pension, their incentives to work in covered employment could be affected (Schwarzer and Querino, 2002) Concern has also been expressed that the level of the benefits may push borderline households to informal employment. However, it is unlikely that the rise in informal employment in Brazil is a direct consequence of this situation. 'Prêvidencia Rural' is focused on informal workers, and entitlement to the BPC is subject to strict means tests (Saboia, 2003). There are few other cases where disincentives to save have been identified as an issue. In low income countries, where social insurance provision is marginal, this is unlikely to apply. Nonetheless, this is an issue to keep in mind for the design of social transfer programmes. 


\section{Concluding Remarks}

Often, concerns are raised regarding the potential impact of social transfers on the macroeconomy, for example on inflation. There is very little information available on this point. Social transfer programmes, even large scale programmes in middle income countries, absorb a very small share of resources and are therefore unlikely to produce macroeconomic effects on a scale which can be observed directly. This applies both to positive growth effects and to negative effects such as inflation. Given the scale of social transfers in developing countries, and the adverse social and economic conditions in which poor households pursue their livelihoods, the growth effects of social transfers could be hard to measure at an aggregate economy level (Levy 2006). This is not because the growth effects of social transfers are unimportant, but because the poor account for a very small share of GDP in developing countries. The macroeconomic effects of social transfers, however small, are present but more analytical approaches are needed to identify and measure them.

Santiago Levy notes that "Progresa-Oportunidades will not directly increase growth...The Programme can contribute to growth as it gradually fosters a healthier and more educated labour force and it allows poor households to make more productive investments that have longer horizons and higher expected returns. But that will not have a first order effect on the country's growth rate. This is because the first two deciles of the income distribution receive less than 2.5 percent of aggregate income in Mexico...If all poor households' income (net of Progresa-Oportunidades transfers) increased by 5 percent a year, aggregate income would increase, at most, by an additional 0.12 percent a year over the growth rate without the program" (Levy 2006, pp. 19-20).

The overall conclusion from this section is that well designed and implemented social transfer programmes can have positive effects on the ability of poor households to invest in their productive capacity, and can therefore support growth strategies among them. Social transfers constitute an effective and essential instrument for supporting growth among the poor and poorest. Social transfers are an important component of a growth strategy, and attention must be given to ensuring that the design and implementation of these programmes help maximise these effects.

The main points from this section can be summarised as follows:

- There is strong support from a range of studies assessing the impact of social transfers for the finding that these ensure increased investment in human development, especially schooling and health service utilisation.

- Reductions in labour supply among children and elders in beneficiary households are often compensated for increases in labour supply among working age adults. Overall, the evidence does not show significant adverse labour supply effects of social transfers among beneficiary households. 
- There is insufficient evidence on whether social transfers have significant positive effect on the local economy, largely because of the scarcity of studies in this area, but studies of PROGRESA/OPORTUNIDADES provide positive examples.

- Social transfers tend to increase saving among beneficiaries.

- The effects on the labour supply and saving of non-beneficiaries is muted, most probably due to the fact that programmes are financed to an important extent by international aid.

- More analytical approaches are needed to identify and measure the macroeconomic effects of social transfer programmes.

\section{Design implications}

The discussion above suggests several important implications for the design of social transfers and their financing.

Social transfers will have important effects upon the income growth of those in poverty to the extent that they facilitate household investment in human and production assets (investment in financial assets is also a possibility). Household investment involves foregoing present consumption to improve the level and stability of future consumption. Social transfers can facilitate investment decisions by raising the incomes of beneficiary households, and therefore their capacity to invest; but also by adding to the stability of income flows in the future, and by providing a floor for consumption.

This has two important implications for the design of social transfers. Firstly, in order to maximise their effects on investment, social transfers need to be regular and reliable. Regularity involves incorporating within the programme clear and transparent rules on eligibility, and on the time period for the entitlements. Duration is important too. The time period during which households are supported needs to be long enough to influence the consumption-investment decision of households, and not too long to generate dependency. This will vary across households of different type and composition. Expectations of households exiting the programme successfully will need to take account of household heterogeneity and concurrent economic conditions. It is important that transfers are disbursed in a timely fashion, to facilitate household budget management. Beneficiary households must have clear and credible information on the size, time and schedule of entitlements.

The level of the transfer is important too. Many income transfer programmes targeting poorest households, PROGRESA/OPORTUNIDADES for example, transfer around 20 percent of average household consumptionin programme areas. Even in the case of noncontributory pensions which define the level of entitlement only on individual older people, 
the fact that the transfer is shared within the household means that it is a fraction of household consumption. In theory, the level of the transfer should depend on the objectives of the programme. Eradicating poverty suggests transfers that bridge the gap between poor households' income or expenditure and the poverty line. Ensuring children schooling suggests a transfer covering the direct and indirect costs to the household of children's education. Lifting poor households onto a growth path, as in Figure 1 above, recommends transfers that place households above effective work capacity. Ensuring household security suggests transfers to vary with shocks. In practice, the level of the transfer is strongly determined by national policy processes and financial conditions. Often, national policy processes rely on an insufficient analytical basis. Broadly, and keeping all other design features constant, a higher level of transfers should result in a higher level of household investment, but attention needs to be paid to thresholds. Where transfers are set at a very low level relative to household consumption, household investment following the transfer will be at best marginal. Significant levels of household investment are more likely to kick in after basic consumption levels are reached in a reliable and sustainable way.

\section{Ethiopia: The National Food Security Programme (NFSP) and growth objectives}

The Government of Ethiopia introduced the National Food Security Programme in January 2005 with donor support. The main aim of the programme is to replace emergency food aid with regular and reliable social transfers. The programme includes two main components. Firstly, the Productive Safety Net Programme (PSNP)provides food- or cash-for-work transfers to households with labour capacity and unconditional transfers to households without work capacity. Secondly, other Food Security Programmes provide advice and support for agricultural activities. Programme designers gave strong attention to productive programme features, emphasising graduation and asset accumulation. Preliminary evaluations suggest the Programme has had positive impacts on nutrition and asset protection among beneficiary households. The impacts on productive capacity are stronger where households benefited both from the PSNP and the other Food Security Programmes. There is growing realisation that programme designers had perhaps underestimated the level and duration of the support needed to help poorest households achieve food security. A policy dialogue on the need to broaden the range of NFSP interventions especially for poorest and assetless households has opened up as a result.

It is important to ensure that eligibility conditions do not incorporate incentives for asset depletion. Transfer programmes which make eligibility dependent on relatively liquid asset holdings such as livestock, could generate incentives for divestment of assets. The same applies to eligibility conditions focused on saving. Eligibility conditions dependent on time invariant variables less easily manipulated by potential beneficiaries have fewer disincentive effects, and greater selection effectiveness. On this same point, it is important that eligibility conditions do not include inactivity tests. This is important, for example, in the context of social pensions or family allowances. It is important that pension beneficiaries are able to continue in paid work for as long as possible. This applies especially to adult household members in the case of family allowances. It is important that transfers do not limit the use of productive assets available to the household, either intentionally or unintentionally. 
This takes us to a related point. Transfers should be designed in ways that facilitate household allocation of productive resources. The issue of changes in household composition and resource allocation in response to social transfers are a large knowledge gap. In South Africa, the effect of pension receipt on household composition and deployment has received some attention. The findings from this literature indicate that pension receipt is associated with inactive household members joining the labour force, and active household members migrating in search of work. There is a gender dimension to these changes. Pension receipt by female pensioners in rural areas appears to release younger female members for migration to the city (Ardington et al, 2007) This suggests a measure of household re-composition and re-deployment in response to the transfer. Transfers can therefore facilitate an improvement in household allocation of productive resources. It is important that the design of transfers supports beneficial household responses.

The gendered response to the social pension in South Africa raises the issue of whether channelling the transfer through particular household members has any effects on household investment over and above the effect from the income supplement. In many conditional cash transfer programmes the direct beneficiary is the mother. The expectation here is that mothers will be more likely to spend transfers on children (Haddad et al 1997) Another way of saying this is that strengthening the influence of the mother in household resource allocation is more likely to strengthen household investment. Broadening this point a bit more, the issue is whether the gender of the transfer beneficiary makes a difference for the effectiveness with which it stimulates investment and facilitates a more efficient resource allocation within the household.

The design of social transfers could include complementary asset accumulation interventions. This should include human capital and other productive assets. In terms of human capital assets, social transfers will be effective in facilitating accumulation and protection of these assets in combination with programmes that ensure basic services, especially education and health care, are available in appropriate quantity and quality. As regards other productive assets, the basic design objective behind BRAC's Challenging the Frontiers of Poverty Reduction/Targeting the Ultra Poor Programme in Bangladesh has been to combine in sequential manner, transfers and human capital interventions with micro-credit and skills. BRAC considers the sequencing of the interventions to be crucial to their effectiveness. Complementing of social transfers with asset accumulation interventions is currently being pursued by OPORTUNIDADES in urban areas of Mexico.

Few social transfer schemes include asset protection components, but it is worth thinking carefully about how these components could be incorporated. Income transfers provide a measure of asset protection in the event of shocks, but for transfers that are fixed in level the protection is limited by the size of the transfer. Social transfers related to public works have stronger insurance components. The NREGS in India, for example, has an explicit insurance component, as it guarantees up to 100 days employment per year. Conditional cash transfers have limited insurance components in restricting the use of children's time as a means of coping with shocks (De Janvry et al, 2006). It might be worth considering whether the level of the transfers could be linked locally more explicitly to addressing the impact of 
covariate shocks, e.g. droughts or flooding. Social transfers could thus acquire income maintenance features.

When considering the design implications of attempting to maximise income growth effects it is important to take account of context. The majority of social transfer programmes in developing countries have been introduced in fairly adverse economic conditions, in which economic opportunities are scarce and much less likely to reach the poorest. Many programmes have been explicitly introduced to address the adverse consequences of liberalisation and decline of agriculture. In this context, transfer programmes can be seen to be successful if they prevent a worse situation as regards asset destruction and depletion.

Knowledge on minimising adverse employment effects of transfers using programme design features is well advanced (Moffitt, 2002) In terms of transfers conditional on labour supply, the level of the transfers should be set below the market wage to minimise adverse incentives. Income transfers should avoid inactivity tests, or means tests based on labour income.

Regarding potential adverse incentive effects on non-beneficiaries, these would more appropriately be associated with the financing of the programmes. This is not a significant issue at present because many transfer programmes are externally financed. However, in the medium and longer run when programmes are increasingly financed from domestic resources, distortions associated with higher levels of taxation will become more of an issue.

\section{Conclusions and Recommendations}

The Review found important knowledge gaps about the linkages of social transfers and economic growth.

\section{Micro- and macro- level analysis}

At a micro level, plugging the knowledge gaps will require that attention is paid to the following two points.

Firstly, there are good and positive examples where social transfers have moved well ahead in implementing strong evaluation processes, especially compared to other development or poverty reduction interventions. Difference in difference techniques of programme evaluation supported by the evaluation data and processes in PROGRESA, for example, have moved our knowledge of the impact of social transfers several steps forward. However, this is far from being the norm. More needs to be done to ensure that large scale interventions are adequately monitored and evaluated.

Secondly, measuring the growth effects of social transfers to date has been largely a byproduct of other evaluation processes. This is perhaps only to be expected given that growth 
objectives are seldom set explicitly. The next step forward is to identify explicitly the processes needed to generate the data required to test for the growth effects of social transfers in an explicit form. This could be done more effectively and least expensively with new social transfer programmes coming on stream. Improvements in evaluation processes and data will provide a basis for plugging current knowledge gaps. This will ensure that programmes generate the data needed to establish potential growth effects with some measure of certainty.

There is an associated risk which should be noted. Setting new objectives and evaluation processes to include growth effects for ongoing programmes could have the effect of diffusing poverty reduction priorities and therefore programme effectiveness.

At the macro-level, there is much to be done before we are in a position to generate reliable evidence on the growth effects of transfers. The bulk of this work in the context of developed countries has relied upon cross-country regression techniques of analysis. The rewards to this research, especially as regards policy implications, are very small, and perhaps diminishing as increasingly sophisticated econometric techniques throw decreasing amounts of light on this issue. A different approach would focus on exploring ways to link up microwith macro- level analysis. Two alternative lines of research are being tested There is an incipient line of research applying computable general equilibrium analytical techniques to identify macro-level conditions. These techniques are at their strongest when the research objective is to investigate the consistency of social transfers with macro identities, taxation and growth for example. They are at their weakest when the research objective is to throw light on impact and intermediate processes associated with social transfers. Computable general equilibrium techniques can be more flexible than country level regressions, but share a basic 'black box' approach. Another line of research being applied in this area is to explore micro-macro linkages within ex-ante simulations of programme effects. This has greater potential in capturing the behavioural responses to social transfers and aggregating them at the macro level. This is a very promising approach (Bourguignon et al, 2002)

\section{Incorporating growth objectives in social transfer programmes}

The challenge ahead is to combine a range of interventions needed to address the multidimensional factors leading to poverty and poverty persistence. Put differently, the challenge is to build packages of interventions that could provide sustainable, long-term, improvements in well being. Building interventions around the axis of social transfers is currently being pursued and researched. The specific issue of incorporating growth objectives into social transfers is a sub-set of this larger challenge. Some pointers have been identified in the Review: the need to build in security and asset protection, the need to combine transfers with basic service and human development interventions, and the need to ensure transfers have a duration and reliability that facilitates and protects this investment.

It is also important to note a danger here. With a fixed and inadequate anti-poverty budget, it might appear attractive to some policy-makers to focus on those among the poor with the 
most assets and closest to the poverty line. The danger is that a one-sided short-term growth focus might suggest concentrating on the 'low hanging fruit'. There are few if any trade-offs in poverty reduction-growth improvement in the medium and longer run. This has been argued for and documented in the Review.

\section{What to avoid?}

It is important to avoid making social transfers into a 'silver bullet', capable of solving all perceived problems. Properly designed and delivered, social transfers are effective in reducing current poverty and hold the promise of reducing persistent poverty. This should be their primary objective.

Social transfers could also facilitate growth, especially and most effectively in shifting those in poverty onto growth strategies. The Review indicated how social transfers influence intermediate processes which could otherwise obstruct household investment and growth. It will be essential to avoid designing social transfers in ways that are inconsistent with growth objectives.

It is important not to ignore the dynamics of social transfers. Social transfers that currently reduce poverty and are consistent with growth objectives may not do so in the future, or in different environments. Many potentially adverse effects of social transfers on the saving and work incentives of non-beneficiaries are not significant today because of the dominant financial modalities behind the spread of transfer programmes, mainly international aid in low income countries. However, an inevitable, and desirable, shift to domestic financing will require us to consider these adverse effects in some detail, and to learn how they could be minimised. Similarly, demographic and economic change may well undermine the sustainability and effectiveness of current programmes. Future research on social transfers should consider urgently the growth effects of social transfers in conditions where these are financed from domestic revenues. This work will be important in arriving at a rounded and comprehensive assessment of the growth effects of social transfers. This is also essential in order to avoid designing and implementing social transfer programmes that are not able to adjust flexibly to changes in these parameters. 


\section{References}

Ahmed A. U. and del Ninno, C. (2002) 'Food for Education Programme in Bangladesh: An evaluation of the Impact on Educational Attainment and Food Security.' Washington DC, USA: International Food Policy Research Institute.

Angelucci M. and De Giorgi, G. (2006) 'Aid and Migration: The impact of PROGRESA on the timing and size of labour migration'. Bonn, Germany: Institute for the Study of Labor (IZA).

Angelucci M. and de Giorgi G. (2006) 'Indirect effects of an aid program. The case of PROGRESA and consumption'. Bonn, Germany: Institute for the Study of Labor (IZA).

Ardington, C., Case A. and Hosegood V. (2007) 'Labour supply responses to large social transfers: Longitudinal evidence from South Africa' Cambridge MA: National Bureau of Economic Research.

Arjona, R., Ladaique M. and Pearson, M. (2001) 'Growth, Inequality and Social Protection.' Paris, France: OECD publications.

Atkinson, A. B. (1999) The economic consequences of rolling back the welfare state. Cambridge, M.A.: MIT Press

Banerjee A. V. and Duflo E. (2004) 'Growth theory through the lens of development economics.' MIT Department of Economics Working Paper Series, (Cambridge, M.A: MIT).

Barrientos A. and Sabates-Wheeler, R. (2007) 'Local economy effects of social transfers.' Brighton, UK: IDS.

Barrientos, A. (2007) 'Does vulnerability create poverty traps?' Manchester, UK: IDPM.

J. Morduch, (1995) 'Income Smoothing and Consumption Smoothing', Journal of Economic Perspectives, vol. 9, no. 3 , pp. 103-14.

Bertrand, M., Mullainathan S. and Miller, D. (2003) 'Public Policy and Extended Families: Evidence from Pensions in South Africa', World Bank Economic Review, vol. 17, no. 1, pp. 27-50.

Bonturi, M. (2002) 'The Brazilian pension system: recent reforms and challenges ahead.' Paris, France, OECD.

Bourguignon, F. (2004) 'The poverty-growth-inequality triangle.' Washington DC, USA: Center for Economic and Policy Research.

Bourguignon, F., Ferreira, F. H. G. and Leite P. G. (2002) 'Conditional cash transfers, schooling and child labour: Microsimulating Bolsa Escola.' Washington DC, USA.: World Bank.

Cardoso E. and Portela Souza, A. (2003) The impacts of cash transfers on child labor and school attendance in Brazil .' Sao Paolo, Brazil: University of Sao Paolo.

Carvalho, I. (2000) Household Income as a determinant of child labour and school enrollment in Brazil: Evidence from a social security reform'). Mimeo: MIT 
Case, A. (2001) 'Does Money Protect Health Status? Evidence from South African Pensions.' Princeton, NJ, USA, Princeton University.

Chen S. and Ravallion, M. (2005) 'How have the world's poorest fared since the early 1980s?' World Bank Research Observer, vol. 19, (2004), pp. 141-69.

CPRC, 'The Chronic Poverty Report 2004-05.' (Manchester, UK: Chronic Poverty Research Centre).

Clements, B. (1997)'Income distribution and social expenditure in Brazil'. Washington DC, IMF.

De Janvry, A., Finan, F., Sadoulet E. and Vakis R. (2006) 'Can conditional transfer programmes work as safety nets in keeping children at school and from working when exposed to shocks?' Journal of Development Economics, vol. 79, pp. 349-73.

Delgado, G. C. and Cardoso, J. C. (eds.) (2000) A Universalização de Direitos Sociais no Brazil: a Prêvidencia Rural nos anos 90. Brasilia, IPEA.

Dercon S. (ed.), (2005) Insurance against Poverty. Oxford, UK: Oxford University Press.

Dercon S. (2003) 'Risk and poverty: a selective review (or: can social protection reduce poverty?).' Oxford, University of Oxford.

Devereux, S. (2002) 'Safety Nets in Malawi: the Process of Choice.' Brighton: Institute of Development Studies.

Duflo, E. (2003) 'Grandmothers and Granddaughters: Old Age Pensions and Intrahousehold Allocation in South Africa', World Bank Economic Review, vol. 17, no. 1), pp. 1-25.

Gertler, P., Martinez, S. and M. Rubio-Codina (2005), 'Investing cash transfers to raise long term living standards.' Washington DC, USA: World Bank.

Haddad, L., Hoddinott J. and Alderman H. (eds.) (1997), Intrahousehold resource allocation in developing countries. Baltimore and London, Johns Hopkins University Press.

Handa, S., Huerta, M. C., Perez R. and Straffon, B. (2000) Poverty, Inequality and spillover in Mexico's education, health and nutrition program.' Washington DC, IFPRI.

Jalan J. and Ravallion M., (1999) 'Are the poor less well insured? Evidence on vulnerability to income risk in rural China', Journal of Development Economics, vol. 58, pp. 61-81.

Kannan, K. P. (2006) 'Employment and social security for the working poor. Two major initiatives in India.' New Delhi: Government of India.

Lam, D., Leibbrandt M. and Ranchhod V. (2004) 'Labour Force Withdrawal of the Elderly in South Africa.' Cape Town, S.A.: University of Cape Town.

Levy S. (2006) Progress against poverty. Sustaining Mexico's Progresa-Oportunidades Program Washington DC, Brookings Institution Press.

Martinez, S. (2004) 'Pensions, poverty and household investments in Bolivia.' Berkeley CA: University of California at Berkeley.

Martinez, S. 'Invertir el Bonosol para aliviar la pobreza: Retornos económicos en los hogares beneficiarios', in G. Aponte, L. C. Jemio, R. Laserna, S. Martinez, F. Molina, Schulze E. and Skinner E. (eds.), (2007) La Inversión Prudente. Impacto del Bonosol sobre la familia, la equidad social y el crecimiento económico, pp. 109-28. La Paz, Brazil: Agosto. 
McCord, A. (2007) 'The social protection function of short-term public works programmes in the context of chronic poverty', in A. Barrientos and D. Hulme (eds.), Social Protection for the Poor and Poorest: Concepts, Policies and Politics. London, UK: Palgrave Macmillan.

Moffitt, R. A. (2002),'Welfare Programs and Labour Supply', in A. J. Auerbach and M. Feldstein (eds.), Handbook of Public Economics, vol. 4, pp. 2394-430. London, UK: Elsevier

Perotti, R. (1992) 'Fiscal policy, income distribution and growth.' Columbia, USA: Colombia University.

Polanyi, K. (1957)The Great Transformation. Boston, USA: Beacon.

Posel, D., Fairburn J. A. and Lund, F. (2004) 'Labour Migration and Households: A Reconsideration of the Effects of the Social Pension on Labour Supply in South Africa', Economic Modelling, vol. 23, pp. 836-53.

Rabbani, M., Prakash V. A. and Sulaiman, M. (2006) 'Impact Assessment of CFPR/TUP: A descriptive analysis based on 2002-2005 panel data.' Dhaka, Bangladesh: BRAC.

Rawlings L. B. and Rubio G. M. (2003) 'Evaluating the impact of conditional transfer programs: Lessons from Latin America.' Washington DC, USA: the World Bank.

Ray, D. (1998) Development Economics. Princeton, N.J. USA: University of Princeton.

Rubalcava, L., Teruel, G. and Thomas, D. (2002). 'Welfare Design, Women's Empowerment and Income Pooling'. Paper presented at the 2003 Annual Meeting of the Population Association of America. Minneapolis, MN, USA, May 2003.

Saboia, J. (2003) 'Relatório final de pesquisa de campo sobre benefícios não-contributivos para os idosos no Brasil.' Country Report, Rio de Janeiro: Instituto de Economia da Universidade Federal do Rio de Janeiro.

Sadoulet, E., de Janvry A. and Davis, B. (2001) 'Cash transfer programs with income multipliers: PROCAMPO in Mexico', World Development, vol. 29, no. 6, pp. 1043-56.

Sadoulet, E., Finan, F. de Janvry A. and Vakis, R. (2004) 'Can conditional transfer programs improve social risk management? Lessons for education and child labour outcomes.' Washington DC, USA: The World Bank.

Samson, M. (2007) 'Social Cash Transfers', in OECD/Povnet (ed.), Good Practice Notes. Paris, France: OECD.

Schwarzer ,H. (2000) 'Impactos socioeconômicos do sistema de aposentadorias rurais no Brazil Evidências empíricas de un estudio de caso no estado de Pará.' Rio de Janeiro, Brazil: IPEA.

Schwarzer H. and Querino, A. C. (2002) 'Beneficios sociales y los pobres en Brazil: Programas de pensiones no convencionales', in F. Bertranou, C. Solorio and W. van Ginneken (eds.), Pensiones no contributivas y asistenciales pp. 63-124. Santiago, Chile: OIT.

Skoufias, E. (2001) 'Progresa and its impact on the human capital and welfare of households in rural Mexico. A synthesis of the results of an evaluation by IFPRI.' Washington DC, USA.

Stecklov, G., Winters, P., Stampini M. and Davis, B. (2003) 'Can public transfers reduce Mexican migration? A Study based on randomized experimental data.' Rome, Italy: FAO. 
Udry, C. (1996) 'Gender, agricultural production, and the theory of the household', Journal of Political Economy, vol. 101, no. 5, pp. 1010-45.

Yap, Y.-T., Sedlacek G. and Orazem, P. F. (2002) 'Limiting child labor through behavior-based income transfers: An experimental evaluation of the PETI program in rural Brazil.' Washington DC, USA: The World Bank. 


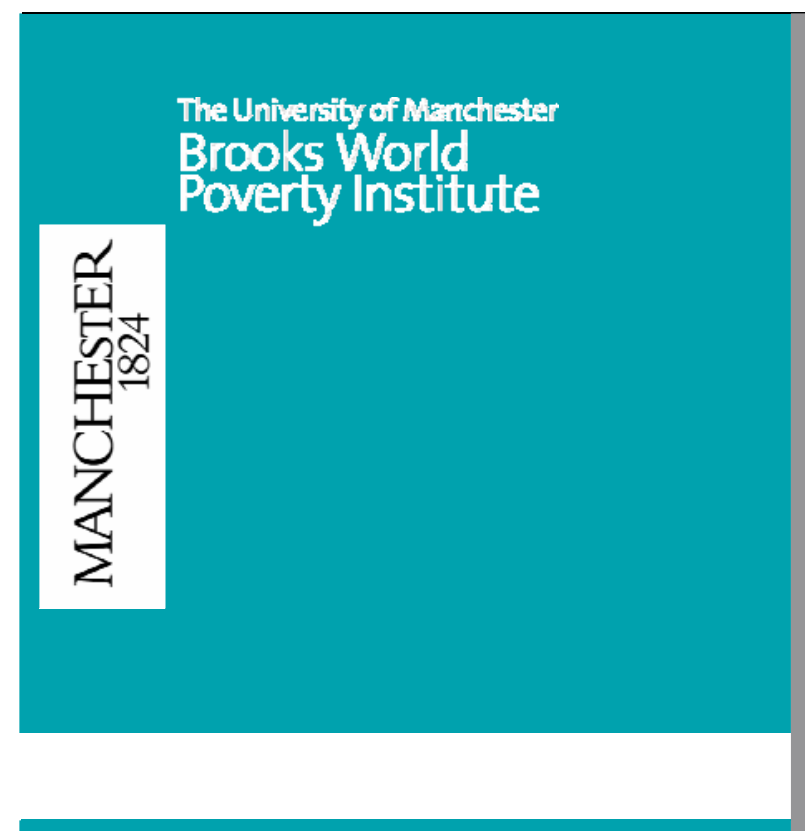

\section{Executive Director}

Professor Tony Addison

Research Director

Professor Michael Woolcock

Associate Director

Professor David Hulme

\section{Contact:}

Brooks World Poverty Institute

The University of Manchester

Humanities Bridgeford Street Building

Oxford Road

Manchester

M13 9PL

United Kingdom
The Brooks World Poverty Institute (BWPI) creates and shares knowledge to help end global poverty.

BWPI is multidisciplinary, researching poverty in both the rich and poor worlds.

Our aim is to better understand why people are poor, what keeps them trapped in poverty and how they can be helped - drawing upon the very best international practice in research and policy making.

The Brooks World Poverty Institute is chaired by Nobel Laureate, Professor Joseph E. Stiglitz. 